\title{
Marching to a Different Drum: The Casserole Protests of the Québec Student Movement, 2011-2012
}

by

Jennifer Berntson

A Graduate Thesis submitted in partial fulfillment of the requirements for the degree of

Master of Arts

in

Music and Culture

Carleton University

Ottawa, Ontario

(C) 2014, Jennifer Berntson 


\section{Abstract}

During the Québec student demonstrations and strike of 2011-2012, the most notorious method of protest used was the rhythmic banging of kitchen utensils, known as les manifestations casseroles (les manifs casseroles). Les manifs casseroles are situated within a larger tradition of collective musical protest by their relationships to other protest movements and to similar protest practices, including the French and French-Canadian tradition of charivari and the Latin American tradition of cacerolazos. The rhythms and sounds of les manifs casseroles created a powerful collective action frame for the student movement, and offered a unique sonic method of expressing dissent, laying claim to public space, and turning unengaged bystanders into artists/activists. 


\section{Table of Contents}

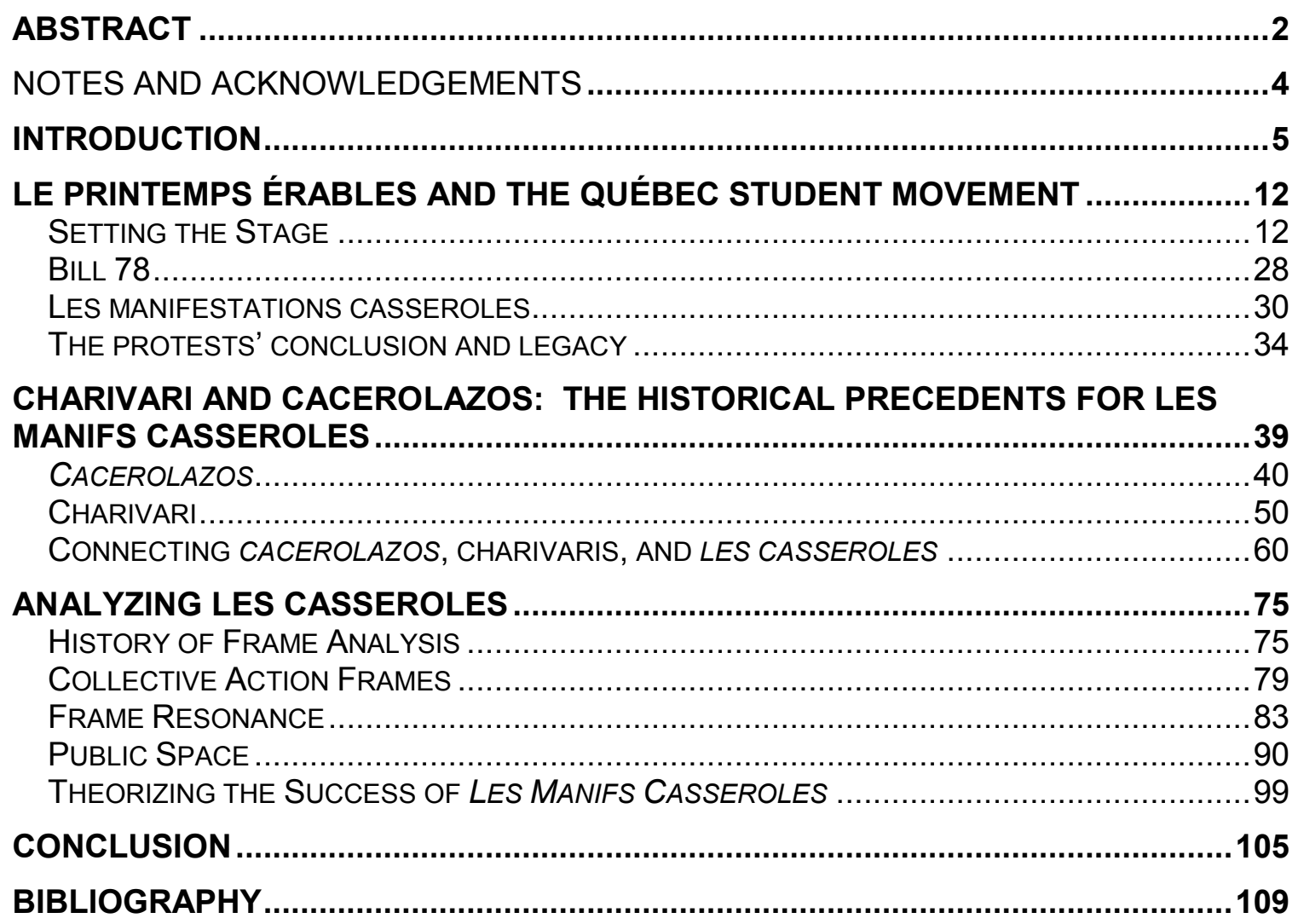




\section{Notes and Acknowledgements}

I would like to express my gratitude to my supervisor Dr. James Deaville for his tireless assistance throughout this project, as well as suggesting the topic to me. Thank you also to the members of the committee-Dr. Michael Mopas, Dr. Jesse Stewart, and Dr. James McGowan—for their time and feedback in reviewing this paper. I would also like to thank the faculty of the Music and Culture program at Carleton University for their guidance, especially Dr. Jesse Stewart, Dr. Anna Hoefnagels, Dr. Geraldine Finn, and Dr. Alexis Luko, whose classes I had the opportunity to take.

I would particularly like to acknowledge my colleagues in the MA Music and Culture program, Esther Wheaton, Ryan Mack, Caroline Vezina, Melba Villamizar-Rodriguez, and Mariam al-Naser: it has been a privilege to witness their academic work, and an even greater one to enjoy their friendship. Lastly, thanks to Shawn Potter for his encouragement throughout this process, and to my family for their support throughout all of my education. 


\section{Introduction}

On est tout petit, des souris, et on fait du bruit.

On va ronger les matraques!

Ce soir, le gros chat laid ne peut rien contre nous.

À qui la rue?

À nous la rue...

Oups, j'ai cassé ma cuillière en bois... Guy Thauvette. ${ }^{1}$

Faisons trembler le Québec!

Éveillons le peuple au ciel

Pour la consécration de notre paix symphonique!

Crions, ensemble: RÉVOLUTION!

Justine Boutin-Bettez. ${ }^{2}$

Living in Montréal, Québec, from 2010-2012, I had the opportunity to witness the largest social mobilization Canada has ever seen. Beginning in winter of 2011 , a series of student demonstrations took place primarily in and around the city in response to tuition hikes by the Liberal provincial government. About 155,000 post-secondary students voted for their student unions to go on "strike" from their education in response to tuition hikes proposed by Jean

\footnotetext{
${ }^{1}$ Guy Thauvette, "Untitled," in Le carré rouge, edited by Marie-Andrée Lamontagne (Montréal: Éditions Fides, 2012), 131.

Translation: We are small, mice, and we make noise.

We will eat away the batons!

Tonight, the large ugly cat can do nothing against us.

Whose is the street?

Ours is the street ...

Oops, I have broken my wooden spoon.

2 Justine Boutin-Bettez, "Untitled," in Le carré rouge, 31.

Translation: Tremble Québec!

Awaken the people to heaven

For the consecration of our symphonic peace!

We cry together: Revolution!

Shout, together: Revolution!
} 
Charest's government. ${ }^{3}$ Thousands of these students took to the streets during the strike to voice their discontent, initially in response to their raised tuition, and later to the controversial introduction of Bill 78 , which limited students' right to protest. Workers' unions, several of the provincial opposition parties (including Parti Québécois and Option Nationale) and other left-oriented groups supported the student movement, which expanded beyond the student population. The protests received international attention, inspiring demonstrations in solidarity across Canada, the United States, and Europe. When Charest lost the 2012 provincial election, the students received a promise from the new Parti Québécois government to roll back the tuition hikes. Even after this achievement, a core group of protesters continued to demonstrate their commitment to universal post-secondary education by hosting protests on the $22^{\text {nd }}$ of every month, in honour of the May 22, 2012 protest that brought a record number of protesters (as many as 400,000 ) to demonstrate in downtown Montréal. ${ }^{4}$

From the beginning, music and sound were a crucial part of these protest events. Through observation of the specific case study of Québec, much can be learned about the role of music and sound in contentious politics, social mobilization, and collective behaviour. The Québec protests featured strong aural components, including rhythmic chanting, body percussion, and occasional ad hoc singing or instrumental trios and quartets. The most famous of these aural

\footnotetext{
${ }^{3}$ Explanation of the term "strike" as applied to student action, as well as discussion of its appropriateness as such, is found on page 22.

4 "Maple Spring: Nearly 1,000 Arrested as Mass Quebec Student Strike Passes 100th Day," Democracy Now! Friday May 25, 2012, http://www.democracynow.org/2012/5/25/maple_spring_nearly_1_000_arrested.
} 
methods of protest was the rhythmic banging of kitchen utensils, known as les manifs casseroles (short for les manifestations casseroles, or the "casserole demonstrations") of May $2012 .{ }^{5}$ Night after night, at $8 \mathrm{pm}$, the sound of casserole pots being struck by wooden spoons or other kitchen implements could be heard ringing through the streets of Montréal. For months on end, the protesters claimed for their own many of the public, cultural, and educational spaces in Montréal, and brought into the public sphere the discourse of revolution. These pots and pans helped to expand the protests beyond the initial student participants, and caught the attention of national and international media. The casserole has become a potent symbol in Québec and around the world, and les manifs casseroles has become a way of embodying protest, through percussion, sound, and collective resistance.

As a musician and as someone invested in social activism, I discovered in the Montréal protest movement interesting questions. Where did les manifs casseroles (the casserole protests) come from - what was root of this highly successful tactic? Why was it so effective, and what did it achieve? And how can sound and music be used to mobilize and engage diverse groups of people for a common goal? Ultimately, it is this last question that is of greatest concern - the question of how music can be harnessed to turn passive citizens into active participants engaged in public discourse and democracy.

In order to consider these questions, I begin by discussing the transformation of different musical traditions into les manifs casseroles, and

\footnotetext{
${ }^{5}$ Throughout this paper, les manifs casseroles and the shortened version, les casseroles, will be used interchangeably to refer to the protests.
} 
situating les casseroles within a larger tradition of collective musical protest by identifying its relationships to other protest movements. This includes the global wave of protests that immediately preceded the Québec student movement: the Québec student demonstrations were generally perceived as associated with and influenced by other transnational expressions of dissent occurring during 2011. For instance, the protests picked up on many of the improvisatory musical and sonic practices of the Occupy movement, which largely took place in autumn of $2011 .^{6}$ Other commentators have even called the Québec movement le printemps érables ("maple spring"), ${ }^{7}$ a play on the similarly pronounced "printemps Arabes," the French translation of "Arab Spring." The protests have also been connected to those that took place that same year in Greece, Spain, and Chile.

In particular, my research will explore the connections between les manifs casseroles, the French custom of charivari, and the Latin American vehicle of protest cacerolazo. A tradition that extended from Medieval France to Francophone communities in North America, charivari has been used for centuries to castigate deviation from community standards and norms, and it is a tradition that has been historically employed in Québec. Most protesters, however, have identified les manifs casseroles as an evolution from the South American cacerolazo, a similar tactic that has been used to protest governmental policies in Chile, Argentina, Uruguay, Venezuela, Colombia, and-in Europe-

\footnotetext{
${ }^{6}$ James Deaville. "The Envoicing of Protest: Occupying Television News Through Sound and Music," Journal of Sonic Studies 3, no. 1 (October 2012), http://journal.sonicstudies.org/vol03/nr01/a05.

${ }^{7}$ See, for example, bibliographic material by Weinstock, Barney, and Sterne.
} 
Spain. Both are collective acts where kitchenware from the private, domestic space is repurposed to become both instrument and political statement. Like in the cases of charivari and cacerolazos, the casserole protests in Québec acted as a tool for communities to hold authority figures accountable to the general public.

Subsequently, this thesis will examine how les casseroles served as a mobilization frame, helping the students gain momentum and maximize participation. Through the use of collective frame analysis, particularly the work of Robert D. Benford and David A. Snow, the elements that made the protests successful in mobilizing will be considered. Another important aspect is the idea that shared rhythmic gesture, such as marching and playing together, is a powerful catalyst for social cohesion. As a form of participatory performance that was inclusive and accessible by nature, les casseroles particularly benefitted from the social bonding that accompanies shared music-making. Ultimately, aside from contextualizing the Montréal protests, I hope to offer insight into the popularity and enduring attraction of casserole protest, whether through les manifs casseroles, charivari or cacerolazos. One may or may not agree with the protesting students, yet their ability to mobilize so effectively shows that les manifs casseroles were an efficient way of engaging citizens in political discourse.

While its participants or observers do not necessarily use the label of music to describe les manifs casseroles, it is a percussive, rhythmic act that is inherently musical. The definition that seems most appropriate to les casseroles 
is what Christopher Small calls "musicking." ${ }^{8}$ Small conceptualizes music as an activity rather than a passive object, one in which participants include not just the performers and conductors, but everyone involved in the creation of the performance, however peripheral they might seem. Thinking of music in this way critiques the elevation of the composer or performer over the audience, and suggests that the value of music is primarily in expressing social relations and meanings. Christopher Small writes:

"Once people become aware that music is in themselves and not only in those who have been selected to become musicians, once they take back to themselves the musical act in a spirit of delight and self-affirmation, who knows what else they might insist on reclaiming, and enjoying, of what has been taken from them?"9

While not all the participants in les manifs casseroles would describe themselves as "musicians," they are in fact using a collective musical activity in their efforts to affirm themselves and their values, as well as reclaim the public space of Montréal from the more violent, riotous protests that preceded les casseroles. It is this act of musicking, and its impact in framing the students' desires and conflicts, that will be explored throughout this thesis.

A few notes about formatting and word choices throughout this paper: when quoting a French language source, I have used the English translation if one has been provided by the original author(s). When no such translation is present, I will quote the original text and supply a translation of my own in the footnotes. When using French or Spanish words within the text, I have italicized

\footnotetext{
${ }^{8}$ Christopher Small, Musicking: The Meanings of Performing and Listening, (Middletown, CT: Wesleyan University Press, 1998), 9.

${ }^{9}$ Christopher Small, "Foreward," in Search and Reflect: A Music Workshop Handbook, (London, UK: Rock School Ltd., 1985), edited by Stevens, iv.
} 
them, as with les manifestations casseroles and cacerolazos. Charivari, while a French practice and term, has been adopted into English as well-as such, it remains in regular text throughout. Montréal and Québec have generally been accented throughout the paper, except when making reference to source materials that have not done so-this can be seen in direct quotations from sources, as well as in titles and other bibliographic details, usually of English language sources. 


\section{Chapter 1:}

\section{Le Printemps Érables and the Québec Student Movement}

This chapter will explore the political and social development of the student protests in Québec, from their origins to their conclusion. It is crucial to begin by contextualizing this student movement as part of a transnational protest phenomenon that included mobilizations in the Middle East, Spain, Greece, Chile, and across North America, since "the forms of action, the narratives and the cultural references of such a struggle cannot be isolated from the wider wave of protests rising throughout the world. ${ }^{10}$ Following accounts of the political, economic, and social situations that led to the broader protest movement, the chapter will continue with a more detailed explanation of the roots of the casserole protests. After considering the impact of les casseroles on media attention and public perception, as well as their role within the larger student movement, it will then explore the decline of the student movement, and relationships to other current protests.

\section{Setting the Stage}

2011 was a year of global protest-it saw the rise of a number of movements that, according to sociologists Charles Tilly and Lesley J. Wood, all constituted attempts to act as "a counterweight to oppressive power, as a

\footnotetext{
${ }^{10}$ Nikos Sotirakopolous and George Sotiropoulos, "'Direct Democracy Now!': The Greek indignados and the present cycle of struggles," Current Sociology 61, no. 4 (2013): 444.
} 
summons to popular action against a wide range of scourges."11 This year of transnational protest began with the self-immolation of a Tunisian grocer in December of 2010, which sparked a wave of demonstrations throughout the Arab world and eventually led to political reform and ousted dictators. ${ }^{12}$ The "Arab Spring," as it was called, saw protesters reject authoritarian rulers and eventually topple the Presidencies of Zine El Abidine Ben Ali in Tunisia, Hosni Mubarak in Egypt, and Muammar al-Gaddafi in Libya; in addition, protests broke out in Syria, Yemen, Bahrain, Morocco, Algeria, and Jordan. Some of these Arab Spring inspired demonstrations led to prolonged and violent revolutions, such as the Libyan Civil War and the ongoing conflict in Syria. The countries where the Arab Spring took root tended to have repressive and corrupt governments, limited social and political freedoms, and were disposed to the use of excessive force in order to maintain their regimes. ${ }^{13}$ It is worth noting, however, that the original act of self-immolation was rooted in socio-economic problems: poverty, and the accompanying powerlessness and social exclusion. ${ }^{14}$

In the middle of an economic recession that had been ongoing since 2009, some Spanish citizens were feeling similarly disenfranchised by their government. Prior to the May 2011 regional elections, the group Democracia Ya organized a march in Madrid that would initiate the $15 \mathrm{M}$ movement, so named

\footnotetext{
${ }^{11}$ Charles Tilly and Lesley J. Wood, Social Movements 1768-2012 (Boulder, CO: Paradigm Publishers, 2012), 4.

${ }^{12}$ Filipe R Campante and David Chor, "Why Was The Arab World Poised for Revolution? Schooling, Economic Opportunities, and Arab Spring," The Journal of Economic Perspectives 26 (Spring 2012): 167.

${ }_{3}$ Abdelkader Abdelali, "Wave of change in the Arab World and chances for a transition to democracy," Contemporary Arab Affairs 6, no. 2 (2013): 202.

${ }^{14}$ Nana Bemma Nti, "Lessons from the Death of a Tunisian Salesman: A Commentary,"African Security Review 22, no. 2 (June 2013): 81.
} 
because it began on the $15^{\text {th }}$ day of May. About 250 of the protesters chose to remain in the Puerta del Sol (Madrid's main square) and set up camp there. Attempts to remove them were blocked by the appearance of thousands of sympathetic activists flocking to the square, their quick response enabled by social networking sites--soon thousands of people were camped in Madrid's central square, where they remained well into June. ${ }^{15} \mathrm{~A}$ majority of these protesters (los/las indignados/as, or "the outraged," as they called themselves) were young Spaniards, who had been particularly hard hit by Spain's spiraling unemployment rate, since as of March 2011, the unemployment rate for those under 24 was 43.6 per cent. ${ }^{16}$ Their poor prospects combined with government corruption and cuts to social, cultural, and educational programs had left them deeply unhappy with their country's direction. ${ }^{17}$ Estimates are that somewhere between 6 and 8 million people participated in the 15M protests before they died down in the late summer of $2011 .{ }^{18}$

The label "indignados" was also given to the Greeks who protested night after night in Syntagma Square during the summer of 2011; one apocryphal story holds that after the Greek austerity package was introduced in May, signs held up by protesters in Puerta del Sol read "Shhhhh... Keep it quiet, we might make

\footnotetext{
${ }^{15}$ Neil Hughes, "Young People Took to the Streets and all of a Sudden all of the Political Parties Got Old': The 15M Movement in Spain," Social Movement Studies 10, no. 4 (November 2011): 408. A later attempt to ban the protests entirely was met with similar resistance.

${ }^{16}$ Ernesto Castañeda, "The Indignados of Spain: A Precedent to Occupy Wall Street," Social Movement Studies 11, no. 3 (November 2012): 310.

${ }^{17}$ Hughes, 410.

18 "Más de seis millones de españoles han participado en el Movimiento 15M," Corporación de Radio y Televisión Española, June 8, 2011, http://www.rtve.es/noticias/20110806/mas-seismillones-espanoles-han-participado-movimiento-15m/452598.shtml.
} 
up the Greeks." ${ }^{\text {19 }}$ Within days, anti-austerity demonstrators began rallying in Syntagma Square through workshops, performances, and demonstrations. About 2 million Greeks have identified themselves as having participated in the protests in some way, and social movement scholars Nikos Sotirakopolous and George Sotiropolous note that many of the protesters were unemployed, or those with "precarious forms of employment"-workers in temporary positions with uncertain futures. It was also comprised of many members of Greece's middle class, whose standard of living had fallen rapidly with rising living costs and pension reforms. Thus, the Greek protesters represented fairly diverse socioeconomic backgrounds, and while they were united by their dislike of austerity measures, there was little else that they agreed upon in terms of political demands. ${ }^{20}$

In the later summer of 2011, the string of transnational protests continued as tensions in Chile flared up. Saddled with a substandard public education system, the legacy of Augusto Pinochet's dictatorship, students began making demands for increased funding for universities, as well as reforms to increase the quality of public education in general, with the goal of making a quality education available to those who could not afford private schooling. Led by a charismatic and articulate student leader, "Commander Camila" Vallejo, the demonstrations were so effectively organized that-with the support of transport and public-

\footnotetext{
${ }^{19}$ Sotirakopoulos et al, 446.

${ }^{20}$ Sotirakopoulos et al, 450 .
} 
sector employees—they could shut down downtown Santiago for days. ${ }^{21}$

Secondary students joined in the protests as well, and when marches and public demonstrations had proved ineffective in changing governmental policy, they began occupying schools. By the end of July, 140 schools in Santiago had been effectively shut down by occupying students, and many of the universities were experiencing striking students and student takeovers of some buildings. ${ }^{22}$

The Chilean students continued their protest into the fall of 2011, when the first Occupy Wall Street (OWS) protests began in the United States. The OWS protests, which took place largely in autumn of 2011, opposed economic inequity along with a host of other social, economic, and environmental issues. Originating in Zuccotti Park, New York City, which protesters occupied for three months, the protests spread to every major American urban center, as well as internationally—at its peak, OWS had groups in over 100 cities and towns around the world. ${ }^{23}$ Tilly and Wood also include movements for gun control, First Nations sovereignty, and against the Keystone $\mathrm{XL}$ tar sands pipeline, as well as the Tea Party movement in their discussion of social movements in North America in $2011 .{ }^{24}$

The occupation of Wall Street, the 15M movement, the Chilean students protests, and the "Arab Spring" have been connected to each other by many scholars, also in popular media and news reporting. Sociologist Ernesto

\footnotetext{
${ }^{21}$ Jonathan Franklin, "Chile's Commander Camila, the student who can shut down a city," The Guardian, August 24, 2011, http://www.theguardian.com/world/2011/aug/24/chile-student-leadercamila-vallejo.

${ }^{22}$ Cesar Guzman-Concha, “The Students' Rebellion in Chile: Occupy Protest or Classic Social Movement," Social Movement Studies 11 (November 2012): 410.

${ }^{23}$ Sasha Costanza-Chock, "Mic Check! Media Cultures and the Occupy Movement," Social Movement Studies 11 (2012): 378.

${ }^{24}$ Tilly and Wood, 3.
} 
Castañeda believes the Occupy movement and the Idignados/as were protesting the same things: a government that did not represent the best interests of the people, valuing big businesses at the expense of taxpayers. Media treatment of the two causes could be similarly dismissive of the protests' potential to elicit policy changes; both groups' lack of specific demands meant that they were criticized as being vague and ineffectual. ${ }^{25}$ When OWS began to spread through North America, many of los indignados were motivated to begin protesting again in solidarity. ${ }^{26}$ Though the Chilean students initiated protests in the summer before Occupy had taken root, they began echoing the rhetoric of Occupy Wall Street: "It's principally the 1 percent who control this country," one student activist told a New York Times reporter. ${ }^{27}$ In general, many of the movements could be characterized as a response to a "global capitalist crisis," the result of the devaluation of labour power and the redistribution of wealth. ${ }^{28}$

In all of these examples, post-secondary education seems to be a key component - public policy specialists and economists Felipe R. Campante and Davin Chor write that:

A vast body of evidence confirms that individuals with a higher educational attainment consistently exhibit a greater propensity to participate in the full spectrum of politic activities, from milder forms of engagement such as voting or discussing politics to more public forms of mobilization such as demonstrations. ${ }^{29}$

\footnotetext{
${ }^{25}$ Andrés Cala, "Spain's Indignados: The 'Original' Occupy Reemerges with Force," Christian Science Monitor, May 16, 2012, http://www.csmonitor.com/World/Europe/2012/0516/Spain-sIndignados-The-original-Occupy-reemerges-with-force.

${ }^{26}$ Ryan Gallagher, "The 'Occupy' Movement's Spanish Roots," New Statesman, October 11, 2011, http://www.newstatesman.com/blogs/the-staggers/2011/10/occupy-movement-madrid.

${ }^{27}$ Francisco Goldman, "Camila Vallejo, the World's Most Glamourous Revolutionary," New York Times, April 5, 2012, http://www.nytimes.com/2012/04/08/magazine/camila-vallejo-the-worldsmost-glamorous-revolutionary.html?pagewanted=all\&_r=0.

${ }^{28}$ Sotirakopoulos et al, 444 .

${ }^{29}$ Campante, 168.
} 
They theorize that the expansion of education in the Arab world was a critical component of the Arab Spring's conception, and notes that those nations with higher education levels and also high unemployment are the most prone to experiencing protest movements. Craig J. Jenkins and Michael Wallace have similarly found greater education and youthfulness as significantly associated with protest activism, as well as with acceptance and support of protest movements. ${ }^{30}$ In all of the cases discussed above, educated youth and particularly university students played a crucial organizational role in these movements. The core of the $15 \mathrm{M}$ movement comprised students and youth concerned about their economic prospects, with the movement particularly acting as a "venue for the discontented college-educated youth who cannot find jobs that pay enough to cover rent and basic expenses." ${ }^{\text {31 }}$ Sotirakopolous and Sotiropolous write that the protesters in Syntagma Square were very often "young people who have been well educated but find that their knowledge cannot be capitalized into a successful career or even a stable occupation." ${ }^{32}$ Students were front and center in many OWS protests, making up approximately $25 \%$ of Zucotti Park protesters. ${ }^{33}$ And Chilean students were responsible for the largest protest movement since the last days of the Pinochet dictatorship.

\footnotetext{
${ }^{30}$ Craig J. Jenkins and Michael Wallace. "Generalized Action Potential of Protest Movements: The New Class, Social Trends, and Political Exclusion Explanations," Sociological Forum 2, no. 2 (June 1996): 196 and 202, http://www.jstor.org/stable/684837. For further information on the correlation between political activism and education levels, see Mayer (2011), Sondheimer and Green (2010), Glaeser, Ponzetto, and Shleifer (2007), and Hillygus (2005).

${ }^{31}$ Castañeda, 309.

${ }^{32}$ Sotirakopoulos et al, 450.

${ }^{33}$ Michael A. McCarthy, "Occupying Higher Education: The Revival of the Student Movement," New Labor Forum 21, no. 2 (Spring 2012): 51.
} 
It is not my intention to equate these movements with each other, or to deny that each took place within distinct cultural, political, and historical contexts. Similarly, I do not claim to have found a concrete causal link between these movements, which would be an exceptionally difficult task. Nonetheless, it is important to acknowledge the wider wave of protest movements of which the Montréal student demonstrations were a part.

With all these activist movements taking place, protest and social mobilization were prevalent topics of discussion, setting the stage for Québec's student mobilization. ${ }^{34}$ As student leader Gabriel Nadeau told newspaper Le Devoir, "There is something in the air. There is momentum. The Arab Spring, the indignés, the Occupy movement... There is an entire discourse being advanced about the interests the governments serve. They do not work for the majority." ${ }^{35}$ So when, in March of 2011, on the advice of the Conférence des recteurs et des principaux des universités du Québec, ${ }^{36}$ Jean Charest's liberal government proposed a tuition increase, the students who opposed the increase became another part of this larger trend of transnational social mobilization. ${ }^{37}$ Some students deemed the $75 \%$ provincial hike in student fees, spread out over five years, regressive; often, these students felt that the province should be striving for the progressive introduction of free higher education, rather than raising fees.

\footnotetext{
${ }^{34}$ Simone Natale, "Talking of Revolution, Again: Interview with Fred Turner," Wi Journal of Mobile Media 6, No. 3 (2012), http://wi.mobilities.ca/talking-of-revolution-again-interview-with-fred-turner/. ${ }^{35}$ Richard Fiddler, "Massive Demonstrations Support Students Striking Against Fee Hikes," Global Research March 21, 2012, http://www.globalresearch.ca/massive-demonstrations-support-students-striking-against-fee-hikes/29882\#sthash.zWpxF2FP.dpuf.

${ }^{36}$ The association of university presidents.

${ }^{37}$ Violaine Lemay and Marie-Neige Laperrière, "Student Protests and Government Somersaults: The Spring from a Law and Society Perspective," Canadian Journal of Law and Society 27 (2012): 440.
} 
They pointed to other problems currently facing the student population, including high youth unemployment, that make tuition increasingly difficult to afford, leading students to take on higher and higher debt loads.

In this context, students referenced the International Covenant on Economic, Social, and Cultural Rights, a UNESCO declaration ratified by the Québec government in 1973. Article 13, section 2c states that "Higher education shall be made equally accessible to all, on the basis of capacity, by every appropriate means, and in particular by the progressive introduction of free education." The students felt that tuition increases represented a betrayal of this ideal. ${ }^{38}$ Other countries that ratified the treaty, such as Norway, Finland, Brazil, and France, have adopted a system of universal university education, a principle for which Québec students believe their government should be striving. ${ }^{39}$ As the Coalition large de l'Association pour une solidarité syndicale étudiante (CLASSE) — a temporary coalition of student societies created with the aim of repealing the tuition hike—stated in the English version of their Manifesto, "We now know that equal access to public services is vital to the common good. And access can only be equal if it is free." ${ }^{40}$ Their logic is that tuition acts like a barrier to achieving higher education, and eliminating tuition "removes the

\footnotetext{
${ }^{38}$ International Covenant on Civil and Political Rights, UNESCO Resolution 2200A, United Nations General Assembly, Res 2200A (XXI), (XXI), 23 March 1966, available from http://www.ohchr.org/en/professionalinterest/pages/ccpr.aspx.

${ }^{39}$ Kim Sawchuk, "La grève est étudiant/e, la lutte est populaire: the Québec Student Strike," Canadian Journal of Communication 37 (2012): 500.

${ }^{40}$ While CLASSE was not the largest Québec student union, it represented around $75 \%$ of the striking students, and in discussions with the government and media, tended to appear as the most radical and uncompromising union "Manifesto," CLASSE, 2012, http://www.stopthehike.ca/manifesto/.
} 
stumbling-blocks to the full flowering of our status as humans." ${ }^{41}$

With students relying on loans to pay for their university educations, student debt was identified by CLASSE and fellow student organizations the Fédération étudiante universitaire du Québec (FEUQ) and the Fédération étudiante collégiale du Québec (FECQ) as a critical obstacle to enabling free access. An estimated $14 \%$ of students in Canada default on their government loans due to their inability to find steady employment after completing university; youth unemployment is nearly double the Canadian national average, and Canadian students are in debt for a total of $\$ 20$ billion dollars ${ }^{42}$ Currently, the average student debt in Canada excluding Québec is almost $\$ 27,000$; largely due to Québec's lower tuition, the average debt in that province is considerably lower at $\$ 13,000$. The comparatively high percentage of youth in post-secondary education in Québec—83\% of Québec youth enroll in post-secondary education, as compared to the overall Canadian average of $74 \%$-also seems to support the student protesters' assertion that high tuition prevents some students from pursuing higher education. Student protesters in Québec would argue that raising their tuition is the first step by the government to raising fees to make them on par with the rest of Canada - tuition in Ontario, which is now over $\$ 6000$, was similar to Québec's $\$ 2519$ in the early 1990 s. $^{43}$

\footnotetext{
41 "Manifesto," CLASSE.

${ }^{42}$ Alice Klein, "Student Protests by the Numbers," Rabble.ca, June 5, 2012, http://rabble.ca/columnists/2012/06/-student-protests-numbers.

${ }^{43}$ Amelia Schonbek, "The Long March: On the Front Lines with Quebec's Student Protestors," The Walrus, Sept. 12, 2012, http://thewalrus.ca/the-long-march/?ref=2012.09-firsthand-the-longmarch.
} 
In mid-February of 2012, the student associations chose to take more direct action in expressing their dissent, and they began refusing to attend classes, blockading doorways, and intercepting professors and students who were still attempting to enter the school. News media have asserted that this represents a boycott, since it involves consumers (students) rejecting the commodity that they have purchased (education). However, the students generally have envisioned themselves as active participants in the institution of education, and believe that their work contributes positively to their society. Consequently, they feel that the term strike is more accurate in describing their intentions. ${ }^{44}$ Québec has a long history of students withdrawing from educational institutions as an act of protest; temporary stoppages such as these have served as a regular tactic used when governments have threatened to raise tuition or decrease funding of loans and bursaries. University of Québec economist Eric Pineault acknowledges that while striking is not a legal right of student associations, "these forms of student action seemed, until the 2012 strike, to have had an unquestioned cultural legitimacy." ${ }^{45}$

Québec's history of student striking dates back to the walkout at Montréal's Protestant Aberdeen School in 1913, when a sixth grade teacher's anti-Semitic comments caused hundreds of students to leave their classrooms in "a strategic

\footnotetext{
${ }^{44}$ Sawchuk, 2012. In addition, the term "strike" has been used in most scholarly literature to describe previous student strikes. For this reason, as well as out of deference to the students' preferred designation, I will be using the term when referring to their actions, despite the fact that only labour unions have the legal ability to strike.

${ }^{45}$ Eric Pineault, "Québec's Red Spring: An Essay on Ideology and Social Conflict at the End of Neoliberalism," Studies in Political Economy 90 (Autumn 2012): 42.
} 
response to perceived injustice. ${ }^{46}$ Beginning in the 1960's, strikes were used as a form of protest against unequal representation of francophonie in postsecondary education. In the last twenty years prior to the 'Maple Spring,' Quebec students have used the tactic of striking twice, both times with great success. In 1996, 60,000 students protested Lucien Bouchard's attempt to unfreeze tuition; ultimately, a compromise was reached with the students so that tuition was raised $30 \%$ and then frozen again. And in 2005 , the Charest government proposed turning provincial funding for financial aid and grants into a student loan program, prompting 170,000 students to strike for three months. In the end, the government made the changes temporary and reinstated full funding for financial aid and grants after a set period of time. ${ }^{47}$

The student strike of 2011, however, is by far the longest and most involved in Québec history—and Canadian history, as well, since student strikes are rare outside of Québec. ${ }^{48}$ Nonetheless, it did not enjoy unqualified public support, and was a highly divisive political issue within Québec. Université de Québec economist Pierre Fortin points out that the proposed raise would have students paying for almost $20 \%$ of the total cost of their education, the same rate they were paying when tuition was frozen in 1994 (currently they cover only $12 \%$ of their education).$^{49}$ Université de Montréal economist Claude Montmarquette believes Québec universities are chronically underfunded, and that $75 \%$ of the

\footnotetext{
${ }^{46}$ Roderick MacLeod and Mary Anne Poutanen, "Little Fists for Social Justice: Anti-Semitism, Community, and Montréal's Aberdeen School Strike," Labour/Le Travail 70 (2012): 62.

${ }^{47}$ Allison Cross, "Canada's 'Maple Spring?' Dissecting the longest student protest in Québec's history," National Post, May 3, 2012, http://news.nationalpost.com/2012/05/03/quebec-studentstrike/.

${ }^{48}$ Schonbek, 2012.

${ }^{49}$ Ray Conlogue, "Why Did They Strike?" Literary Review of Canada Dec, 2012, http://reviewcanada.ca/magazine/2012/11/why-did-they-strike/.
} 
funding gap between Québec universities and the rest of Canada can be directly attributed to the province's lower tuition rates. ${ }^{50}$

Another argument widely made was that the tuition hikes, if properly balanced out by a grants-and-loans system, would not have made higher education as inaccessible as the students argued it would. The tuition hikes would have been partially used to increase funding to Aide financière aux études (AFÉ), the organization that administers loans and bursaries to students; $\$ 118$ million was given the AFÉ in the 2011 budget, and Education Minister Line Beauchamp announced on April 5, 2012, that a further $\$ 21$ million would be provided. ${ }^{51}$ This extra funding would have allowed for the creation of more grants and bursaries assisting students from lower income families, and would have effectively meant a decrease in tuition for students from families earning less than $\$ 45,000$ a year. Economist Luc Godbout at the Université of Sherbrooke argued that a continued tuition freeze effectively "subsidizes students from rich families who attend university in greater proportion.. ${ }^{52}$

It is worth noting as well that the students themselves were hardly a monolithic group, with sources reporting that only one-third to one-half of

\footnotetext{
${ }^{50} \mathrm{Jim}$ Hynes, "Mind the gap: Montmarquette says underfunding a real problem," McGill Newsroom, Feb. 23, 2013, http://www.mcgill.ca/newsroom/channels/news/mind-gapmontmarquette-says-underfunding-real-problem-225146.

${ }^{51}$ Tommy Chouinard and Paul Journet, "Québec élargit son programme de prêts pour études supérieures," La Presse, April 5, 2012, http://www.lapresse.ca/actualites/education/201204/05/01-4512709--elargit-son-programme-deprets-pour-etudes-superieures.php.

${ }^{5}$ Stephanie Forster, "Facts don't back the protesters' claims," The Chronicle Herald, May 6 2012, http://thechronicleherald.ca/thenovascotian/93290-facts-don-t-back-protesters-claims. This argument is imperfect in that it assumes families with larger incomes choose to financially support their children's education, however.
} 
Québec's university students participated in the student strike. ${ }^{53}$ Students in the Université de Montréal Faculty of Law were the first of several groups and individuals to file an injunction in the Superior Court, attempting to ensure the availability of classes and instructors regardless of the strike. While their injunction was unsuccessful, they paved the way for other more successful injunctions—none of them, however, were effective in guaranteeing access to education during the course of the actual strike. ${ }^{54}$ As of July 2013 , at least one student had successfully sued the University of Laval history students' association for reimbursement of one semester's worth of tuition and gas money. ${ }^{55}$ Even students who supported the strike were not unified, as evidenced by an incident on May 1, 2012, when one group of students interrupted a press conference held by another. A formal joint FEUQ and FECQ conference on proposed responses to the government's most recent communications was interrupted by masked hecklers, at least one of whom claimed affiliation with CLASSE. The student unions struggled to agree on specific demands for the government, and as a result were sometimes paralyzed by infighting and dissension. ${ }^{56}$

\footnotetext{
${ }^{53}$ Cross, 2012. Number estimates vary according to sources; they are as high as 300,000 by some estimations, and closer to 185,000 by others. Regardless of their exact numbers, they did represent a significant number of students.

${ }^{54}$ Lemay and Paperriere, 442.

55 Graeme Hamilton, "Student Association Ordered to Reimburse man \$1,220 in lost tuition after forced strike last year," National Post, August 19, 2013, http://news.nationalpost.com/2013/08/19/student-association-ordered-to-reimburse--man-1220-inlost-tuition-after-forced-strike-last-year/

${ }^{56}$ Robyn Urback, "Quebec's Student Strikers Turn on Themselves," National Post, May 2, 2012, http://fullcomment.nationalpost.com/2012/05/02/robyn-urback-quebecs-student-strikers-turn-onthemselves/.
} 
From outside of Québec, the criticism was even stronger-the comments about an August 13 National Post article, "Student association ordered to reimburse man $\$ 1,220$ in lost tuition after forced strike last year" reveal the vitriol with which some Anglo-Canadians viewed the protesters. ${ }^{57}$ Margaret Wente's The Globe and Mail editorial "Québec's tuition protesters are the Greeks of Canada" reveals some of the disdain with which certain other Canadians, all of whom pay much more tuition than the protesting Quebeckers, feel towards the movement. She writes that Canadians "cannot understand why so many students would get so worked up over such moderate tuition hikes, which would still leave them with the lowest tuition in North America," and describes the rest of Canada as looking on, "appalled."

The students accompanied their strike with protests, the first major one taking place on November 10, 2011, when 20,000 students marched on premier Jean Charest's office. This demonstration, like the others, was the combined effort of student unions, the most highly visible being CLASSE. CLASSE developed a rhetoric supporting the use of public space as a venue for voicing demands—as their manifesto states, "The way we see it, direct democracy should be experienced, every moment of every day. Our own voices ought to be heard in assemblies in schools, at work, in our neighbourhoods." ${ }^{59}$ After several weeks of relative quiet, the CBC news article "37 arrested at Quebec student

\footnotetext{
${ }^{57}$ Commentater cslos 77 called the students "self-entitled brats," language that has been often used to describe the movement. Other even more colourful commenters compared the student tactics to Nazism. Hamilton, "Student Association Ordered to Reimburse..." 2013.

${ }^{58}$ Margaret Wente, "Quebec's tuition protestors are the Greeks of Canada," The Globe and Mail, May 19, 2012, http://www.theglobeandmail.com/commentary/quebecs-tuition-protesters-are-thegreeks-of-canada/article4186821/.

59 "Manifesto," CLASSE.
} 
protest" on February 17, 2012 reported that students were arrested for breaking into a CÉGEP in downtown Montréal earlier that day. After this night, students would organize daily protests well into May of that year.

Only six days after the start of the nightly protests, on February 23 , police used pepper spray on demonstrators who were disrupting rush hour traffic. A young protester on March 7 hit by a stun grenade thrown by police nearly lost the use of one of his eyes. These were among the first reports of a variety of tactics police would use over the next three months in suppressing the protests. Pepper spray served as a deterrent on many occasions, most famously, on bystanders enjoying drinks on a brasserie terrace one summer evening, a story that received widespread media coverage ${ }^{60}$ The Montréal police also used a crowd control technique known as kettling, whereby officers boxed in protesters, controlling access to and from the location. The use of kettling has been controversial, particularly at the G20 summit in Toronto, but also during the Montréal protests. The CBC news article "Crowd control: What is kettling?" (May 24, 2012) noted that while the European Court of Human Rights has cited kettling as an effective nonviolent tactic, it often leads to bystanders becoming trapped within the demonstration. It can also deprive protestors of sleep, nourishment, and proper hygiene when they are trapped in an enclosed space for hours at a time, as happened during the Montréal student protests. The practice of kettling and the brasserie pepper-spraying incident played a role in eliciting public sympathy for the students, which the students then capitalized on to increase their popularity.

\footnotetext{
${ }^{60}$ Cayley Sarochan, "The Québec Student Strike - A Chronology," Theory and Event 15, no. 3 (2012), doi:10.1353/tae.2012.0030.
} 
On March 22, the largest demonstration yet occurred, with well over 100,000 protesters, creating a parade that media sources estimated as somewhere between two and four kilometers long. Organizers cited it as their most successful protest yet, claiming that participation was as high as 200,000 , and that the rally extended 50 city blocks at its height. Throughout April, difficulties continued to plague attempts to negotiate an agreement between the Québec government and the student unions. Charest's calls for student groups to condemn vandalism were ignored by CLASSE, resulting in the Premier's refusal to meet with the group. Similarly, all compromises offered by the government were rejected by the student unions, culminating in the resignation of Education minister Line Beauchamp. ${ }^{61}$ All of these events led up to Charest's announcement on May 16 that Québec was tabling la loi spéciale, the emergency law that would suspend the current semester and force students to complete their semesters in the fall.

\section{Bill 78}

The "special law" would become Bill 78, a temporary bill branding all public gatherings involving more than 50 people illegal unless an itinerary was provided to the police more than eight hours in advance. ${ }^{62}$ The Bill also included anti-mask provisions, prohibiting the wearing of face coverings at public gatherings. Gatherings in communal space are a common feature of life in

\footnotetext{
${ }^{61}$ Sarochan, 2012.

62 Interestingly, the rarely-enforced Montréal Bylaw P-6 already contained provisions against the wearing of masks during protests, and requiring protests to provide a route to the police in advance. Efforts to repeal these provisions made in spring of 2013 were unsuccessful. ('City council votes for status quo on controversial protest bylaw P6," CTV Montreal, April 23, 2013, http://montreal.ctvnews.ca/city-council-votes-for-status-quo-on-controversial-protest-bylaw-p61.1251309.)
} 
Montréal, and thus this bill effectively made illegal a large number of activities taking place in public spaces around the city. The Police proved they were willing to use Bill 78 almost immediately after its passing: a week after the Bill's announcement, Montréal police arrested 506 protestors caught in the area they surrounded for the crime of illegal assembly, using the technique of kettling described earlier. Protesters were fined up to $\$ 700$ for contravening Bill 78 . In a single night, police made more arrests than during the entirety of the October Crisis of 1970, when martial law was imposed under the War Measures Act-and this only includes those arrested for illegal assembly, not those arrested for other crimes. ${ }^{63}$ These two developments-the introduction of Bill 78 and the mass arrests—aroused vigorous public opposition, and ultimately spurred les manifestations casseroles.

Taking advantage of the public sentiment against Bill 78 after its announcement on May 16, CLASSE attempted to reposition the protests as a broader ideological movement against the distribution of wealth in Québec, and the economic structure that supported the political and economic elite. They voiced wider displeasure with the Charest government over more than just tuition hikes, mentioning his economic austerity measures as well as allegations of corruption. ${ }^{64}$ Students saw themselves as standing for Quebec's traditional ${ }^{65}$

\footnotetext{
${ }^{63}$ Roberto Rocha and Max Harrold, "Police round up 518 protestors in one night," Montréal Gazette, May 24, 2012, http://www.montrealgazette.com/news/story.html?id=6668555.

${ }^{64}$ Pineault, 30.

${ }^{65}$ Traditional values since the 1960s and the Quiet Revolution.
} 
social-democratic values, while the provisions of Bill 78 and the tuition hikes represented the encroachment of corporatist neoliberalism. ${ }^{66}$

This repositioning had some success, at least to the extent that the student movement gained more support, and from a wider variety of sources. Trade unions voiced their displeasure and joined in with the student protests. The President of the Barreau de Montréal expressed the opinion that Bill 78 represented a violation of constitutional rights, and with hundreds of other lawyers organized a demonstration in front of Palais de Justice, Montréal's main courthouse on May $28 .{ }^{67}$ The United Nations condemned the law as well when High Commissioner of Human Rights Navi Pillay testified before the Human Rights Council in Geneva, Switzerland, that she was "disappointed by the new legislation passed in Quebec that restricts their rights to freedom of association and of peaceful assembly". ${ }^{68}$

\section{Les manifestations casseroles}

Earlier in 2011, the pots and pans made publicized appearances in both Spain and Chile. ${ }^{69}$ In Spain, many South American immigrants counted themselves among the indignados/as. Many of these immigrants had been involved in workers' movements in their countries of origin, and they were the

\footnotetext{
${ }^{66}$ Pineault, 39.

${ }^{67}$ Katherine Leger, "Quebec Lawyers Take to Streets to Protest Bill 78," Canadian Lawyer and Law Times Blog, 9 May 2012, http://www.canadianlawyermag.com/legalfeeds/882/Quebeclawyers-take-to-streets-to-protest-Bill-78.html.

68 "Ottawa defends Bill 78 against UN critique," CBC.ca, June 19, 2012, http://www.cbc.ca/news/canada/Montréal/ottawa-defends-quebec-bill-78-against-un-critique1.1283594.

${ }^{69}$ Cala, 2012.
} 
ones who brought the protest tactic of cacerolazos to the $15 \mathrm{M}$ movement. ${ }^{70}$ The ability to mobilize large groups of supporters very quickly through social media and the ease of access to household objects like pots and pans made cacerolazos a preferred tactic of the Chilean student protesters as well: Vallejo's hundreds of thousands of twitter followers assisted her in initiating cacerolazos, no planning, preparation, or musical talent required. ${ }^{71}$ These same advantages were part of what made les casseroles a useful tool for the Montréal student protesters and their allies.

Les casseroles would become the most memorable and distinctive soundscape of the Montréal protests, but it was not the only sonic component of the protests. Unison chanting has been a standard sonic tool of most protests, those in Montréal being no exception. In addition to chanting slogans and using call and response, protesters took common tunes like "If You're Happy and You Know It" and "The Ants Go Marching" and rewrote the lyrics to critique the Charest government. Impromptu ad hoc instrumental groups often sprang up, and marching bands accompanied the protests on several occasions. Noisemakers, including air horns, whistles, firecrackers, drums, and vuvuzuelas, were frequently used in combination with body percussion and movement, both choreographed and improvisatory. ${ }^{72}$ On at least one occasion, protesters

\footnotetext{
${ }^{70}$ Castañeda, 317.

${ }^{71}$ William Moss Wilson, “Just Don't Call Her Che," The New York Times, January 28, 2012, http://www.nytimes.com/2012/01/29/opinion/sunday/student-protests-rilechile.html?pagewanted=all.

72 Jonathan Sterne, "Québec's \#Casseroles: On Participation, Percussion, and Protest," Theory and Event 15, no. 3 (2012), doi:

http://muse.jhu.edu/journals/theory_and_event/v015/15.3S.sterne.html.
} 
responded to being kettled by turning on a boom box and forming a conga line in an attempt to diffuse a tense situation. ${ }^{73}$

In addition, the demonstrators relied heavily upon pre-recorded music. Owen Chapman, a Concordia Professor and electronic musician, describes how he was inspired by the sounds of the protest to create a music-playing device out of a bike trailer he normally used for transporting his children. With four speakers, a car stereo system, a subwoofer, and a battery, he constructed what he dubbed the "Boogie Buggy." Chapman put together a playlist that combined revolutionary music and dance music, including protest favourites such as "Libérez-nous des libéraux" by Loco Lacass, Public Enemy's "Fight the Power," and Edith Piaf's "Je ne regrette rien." His experience was that wherever the Boogie Buggy went, people erupted into song and dance, bonding with each other over the sounds of protest. $^{74}$

The first casserole protest took place on May 22 , the $100^{\text {th }}$ straight day of protest in Montréal. It was the idea of political science teacher François-Olivier Chené at Cégep de Saint-Hyacinthe, who created a Facebook event shortly after Bill 78 was announced, suggesting that protesters use pots and pans to demonstrate from balconies and sidewalks. ${ }^{75}$ Like most of the other tactics, it seems to have evolved organically, as an idea publicized through social media and spread over Twitter, Facebook, and through word of mouth. At 8 p.m., the

\footnotetext{
${ }^{73}$ Justin Ling, " ${ }^{\text {rd }}$ night of protest under Bill 78: Calm in the streets, 2 arrests, conga line," Open File, May 22, 2012, http://www.openfile.ca/Montréal/Montréal/text/3rd-night-protest-under-bill-782-arrests-calm-streets-conga-line.

${ }^{74}$ Owen Chapman, "The Revolution will be Sonic," Wi Journal of Mobile Media Special issue (2012). http://wi.mobilities.ca/the-revolution-will-be-sonic/.

${ }^{75}$ Les Perraux, "How casseroles overcame cudgels on the streets of Montréal," The Globe and Mail, May 30, 2012, http://www.theglobeandmail.com/news/national/how-casseroles-overcamecudgels-on-the-streets-of-Montréal/article4219644/.
} 
protestors communed in the street, striking saucepans, pots, and frying pans with wooden spoons. Certain neighbourhoods particularly embraced les casseroles, including Notre-Dame-de-Grâce, the Plateau, Villeray, Côte-des-Neiges, PetitePatrie, Rosemont, and St-Henri. In each neighbourhood through which the casserole-bearing parade marched, citizens would get out their own kitchenware and add to the sound, showing and entoning solidarity with the student movement-or perhaps just participating in the joy of collective music-making. ${ }^{76}$ The sonic environment thus created was exciting and impressive enough that it caught media attention around the globe, and mobilized support for the student movement to new levels.

Chené's original plan was quickly abandoned as the number of participating protesters became too great to stay on the sidelines. ${ }^{77}$ Chené calls the massive influx of participants and the spread of the protests to neighbourhoods all over Montréal "very spontaneous," ${ }^{\prime 78}$ and observed that while he may have planted the idea of the protests, it expanded outside of his influence very quickly: "Le mouvement est hors de mon contrôle maintenant." ${ }^{79}$ People found his idea inspiring and adopted it with enthusiasm, but ignored Chené's suggestions to keep to sidewalks, avoid blocking traffic, and keep the protests to 15 minutes. Chené had hoped that following these suggestions would prevent the protests from being declared illegal, and the action would face less backlash; despite the

\footnotetext{
${ }^{76}$ Carrie Rentschler, "On s'en Câlisse, la Loi Spécial: The Music Festival That Wasn't," Wi Journal of Mobile Media Special Issue (2012), http://wi.mobilities.ca/on-sen-calisse-la-loi-specialthe-music-festival-that-wasnt/.

${ }_{78}^{77}$ Perraux, 2012.

${ }^{78}$ Perraux, 2012.

79 "The movement is out of my control now." "Le concert de casseroles atteint Montréal," Canoe.ca, May 23, 2012, http://fr.canoe.ca/infos/regional/archives/2012/05/20120523191848.html.
} 
fact the demonstrations were more confrontational than he envisioned, however, during the initial protests he reported experiencing very little resistance or resentment from either the police or bystanders.

Shouted slogans and unified chanting were still a part of the sonic landscape of the protests; the most common was "la loi spéciale... tack tack..tack tack...on s'en calîsse," which could be mildly translated as "the special law, we don't care about it". The percussive and rhythmic nature of the chanting reflected the way the casseroles were played, and the frequent repetition of this particular chant revealed much about the focus of les casseroles, which was very much on Bill 78 rather than the tuition increase.

In general, les casseroles had a positive impact on the interactions of the protesters with the police. It is a type of protest that reduces barriers to activism by using common, household objects, and eliminating possible language barriers in a bilingual city. In addition, the demonstrations became more accessible-for those with reduced mobility, it was possible to lend support from the relative safety and comfort of a home or apartment balcony. It also requires little planning or forethought, since anyone within earshot knows when and how to join in. As a grassroots movement that had intergenerational appeal, les casseroles expanded the demographics of the protesters to include not just youth and students, but children and adults of all ages.

\section{The protests' conclusion and legacy}

While May of 2012 brought a record number of student-participants in the protests, attendance began falling in late June. The nighttime marches continued 
every evening, but with smaller turnouts and less media attention. Students noticed that politicians who had been supporters of the movement, including then-opposition leader Pauline Marois of the Parti Québécois, stopped wearing their red squares in public. ${ }^{80}$ Student leaders, however, predicted that this was a temporary lull in the movement as students regrouped before the start of the fall semester.

With an election called in the fall of 2012, however, the students would not need to continue their strike. The Parti Québécois, which campaigned on a platform of abolishing the tuition hikes along with Bill 78 , won the provincial election on September 4, 2012 and ended nine years of the Charest Liberal government. They repealed both the tuition hikes and Bill 78, and the students celebrated their protests as a victory. However, in February of 2013, the Parti Québécois instituted a new policy that made tuition rates proportionate to levels of disposable income in Québec. ${ }^{81}$ This amounted to a 3\% tuition hike for the next academic year of 2013-2014; while students voiced their complaints about the tuition hikes, their numbers seem to have been small enough to prevent a second swell of student protest. The FECQ and FEUQ expressed their disappointment over the hike, while ASSÉ (the parent organization of CLASSE, which has since been dissolved) has continued to organize demonstrations on an

\footnotetext{
80 "Protests fizzling out? Crowds shrink notably despite call for mass rally," National Post, June 22, 2012, http://news.nationalpost.com/2012/06/22/crowds-notably-shrinking-in--protests-is-themovement-fizzling-out/.

${ }^{81}$ James Bradshaw and Rhéal Séguin, "Quebec to raise university tuition fees despite strong opposition," February 24, 2013, The Globe and Mail, http://www.theglobeandmail.com/news/national/education/quebec-to-raise-university-tuition-feesdespite-strong-opposition/article9018652/.
} 
intermittent basis, advocating for the eventual abolition of tuition. ${ }^{82}$ For their part, university administrators have been dismissive of the hike, pointing out that the small amount of money it will bring in is entirely insufficient in solving the chronic underfunding of Québec universities. ${ }^{83}$

A commission has been called to review the conduct of both students and police officers during the protests, chaired by Serge Ménard. Hearings began in fall of 2013 , and to date, little has been heard from the results of the commission, which is supposed to examine issues such as crowd control techniques and incidences of personal injury. Both the Fraternité des policiers et policières de Montréal and ASSÉ representatives have refused to meet with the commission, one police spokesperson calling the commission "useless." ${ }^{84}$ Ménard notes that apart from ASSÉ the student unions have been more cooperative.

Ultimately, student leaders view the protest as an unqualified success, and believe that by organizing against Charest and aligning themselves with the opposition, they helped facilitate a change in power that circumvented the proposed $75 \%$ tuition raise. ${ }^{85}$ While the success is usually agreed upon by other sources, there are still unresolved issues-Geoffrey Kelley, a Liberal provincial representative, feels that the students' success is only temporary, since without a solution to university underfunding the issue of tuition will inevitably come up

\footnotetext{
${ }^{82}$ Lemay and Laperriere, 439.

${ }^{83}$ Bradshaw and Séguin, 2013.

${ }^{84}$ Michelle Lalonde, "Commission examining maple spring protests is on-track," The Gazette, August 30, 2013, http://www.montrealgazette.com/news/Commission+examining+maple+spring+protests+track/88 52815/story.html.

${ }^{85}$ Lindsay Michael, "Quebec's student tuition protest: Who really won the dispute?" $C B C$ News, August 18, 2013, http://www.cbc.ca/news/canada/quebec-s-student-tuition-protest-who-reallywon-the-dispute-1.1327562.
} 
again. And though McGill Professor of Law Daniel Weinstock agrees with student leaders that the protests were successful, he feels that people focus too narrowly on tuition fees as defining the success or failure of the movement, noting, "we didn't solve many of the fundamental issues facing education as a whole. Had the protests given rise to questions about equity in education, from daycare to university, and how you ensure that equity and accessibility are guaranteed, that would have made a real difference. It was a missed opportunity. A lot of the energy that might have galvanized a real discussion has by now dissipated." ${ }^{86}$

The surge in protest that took over Montréal from February to September, 2012, and spread to other areas of Québec, was one of the largest protest movements in Canadian history, with at least 750,000 demonstrators participating in the protests. ${ }^{87}$ The student movement has faded, and with it so have les manifs casseroles. However, it is safe to say that we have not heard the last of them from Québec. Their rise to prominence as a tool of protest seems to mark the beginning of a trend; casserole protests have been used since then in support of a variety of Canadian causes, both inside and outside of Québec. $^{88}$ The tactic has come to be acknowledged as an effective, adaptive, and meaningful way of expressing dissent; its success in mobilizing and

\footnotetext{
${ }^{86}$ Michael, "Quebec's student tuition protest," 2013.

${ }^{87}$ Billy Shields, "Were the Quebec student protests worth it?" Global News, September 21, 2014. http://globalnews.ca/news/858944/were-the-quebec-student-protests-worth-it/.

${ }^{88}$ They have appeared at a wide range of events representing a diverse array of issues including. For examples of some of these causes see "Casserole protest marks first year of Marois government," Sept. 5, 2013, http://www.cbc.ca/news/canada/montreal/casserole-protest-marksfirst-year-of-marois-government-1.1369651; Gene Logan, "Exxon Valdez Disaster Anniversary Event," Facebook, March 24, 2013, https://www.facebook.com/events/326048737509369/?source=3\&source_newsfeed_story_type=r egular; Grimsby Lincoln, "Final Turbine Meeting Gets Noisy," Niagara Region News, June 28, 2012, http://www.niagarathisweek.com/news-story/3266290-final-turbine-meeting-gets-noisy/.
} 
expanding the student movement indicates that it was a highly resonant and evocative action. While the immediate social and political chain of events explored in this chapter help to contextualize the movement, an investigation of the broader history and influences behind the casserole protests is necessary in order to understand it more fully. This will enable a more thorough comprehension of the frames of reference through which Quebeckers interpreted les manifs casseroles. 


\section{Chapter 2}

\section{Charivari and Cacerolazos: The historical precedents for les manifs casseroles}

Les manifs casseroles bear similarity to a number of well-established musical rituals and traditions, including the Acadian tintamarre, English "rough music," the Italian scampanate, and the German Katzenmusik, to name a few. ${ }^{89}$ However, there are two traditions in particular that stand out in connection with the Québec protest movement, and whose histories should inform our understanding of the significance and implications of les casseroles. The protesters themselves have frequently cited the South American form of protest cacerolazo as the inspiration for les casseroles: when Québec teacher FrançoisOlivier Chené first suggested incorporating pots and pans into the demonstrations, he was imagining a North American version of the cacerolazo. ${ }^{90}$ The casseroles protests have also been identified by as a descendent of charivari, a 700-year-old francophone practice used to enforce community standards. ${ }^{91}$ A social ritual popular in rural areas of medieval France, the charivari later evolved into a form of political protest in Lower Canada. Looking at scholarly literature on both of these forms of protest provides valuable insights

\footnotetext{
${ }^{89}$ Ronald Labelle, "Tintamarre: A New Acadian Tradition," Encyclopedia of French Cultural Heritage in North America, 2007, http://www.ameriquefrancaise.org/en/article319/Tintamarre:_a_New_Acadian_"Tradition”_.html; Violet Alford, "Rough Music or Charivari." Folklore 70, No. 4 (1959): 508.

${ }^{90}$ François-Olivier Chené, interview by Erica Johnson, The Current, CBC, June 1, 2012. http://www.cbc.ca/thecurrent/episode/2012/06/01/casserole-protests/.

91 Jonathan Sterne, "Québec's Casseroles: On Participation, Percussion, and Protest," Theory and Event 15, no. 3 (2012). http://soundstudiesblog.com/2012/06/04/casseroles/.
} 
into the origins of les casseroles, and the ways it can be theorized and understood.

\section{Cacerolazos}

\section{The March of the Empty Pots and Pans (Chile, 1971)}

One of the many traditions involving the use of pots, pans, and household implements to air public grievances that is most frequently invoked as inspiration by the Québécois student protesters is the South American cacerolazo. Taken from the root cacerola (a stew pot) and azos (to strike), cacerolazo refers to the rhythmic beating of pots and pans to express political dissatisfaction and dissent. Throughout its history, cacerolazos most often have taken place in the streets as part of a march or other demonstration. One of its more unique characteristics, however, is that participants can join in from the privacy and relative convenience of their own homes by adding their own percussive sounds to the demonstration when it passes by, thereby achieving some degree of participation.

Cacerolazos have taken place in Chile, Argentina, Brazil, and Uruguay. However, for the purposes of this paper, a focus specifically on the Chilean context of cacerolazo makes the most meaningful contribution to understanding les casseroles, for two main reasons. First, the initial cacerolazo, as well as the coining of the term itself, occurred in Chile. The first cacerolazos to emerge-the "March of the Empty Pots and Pans," 1971, and the anti-Pinochet cacerolazos of the 1980s—both took place in Chile, and are still among the most famous and highly publicized cacerolazos. Secondly, the protesters in Québec generally label cacerolazos as a "Chilean" tradition, though since its inception in 1971 it has 
been adopted by a growing number of South American countries. Based on statements from the protesters (see page 80-81), it is clear that they were aware of and drew inspiration from the casserole's Chilean history and used it as a frame of reference.

The first cacerolazo occurred in 1971 during Salvador Allende's socialist government, in response to consumer shortages and policies that were redistributing wealth. Allende had formed a coalition of communist, socialist, and left-leaning parties called Unidad Popular (UP), translated Popular Unity in English, winning the 1971 election on the promise of a peaceful, legal transition from a capitalist economy to a socialist one.$^{92}$ Allende's platform horrified conservative Chileans, particularly the middle class, businessmen, and landowners who relied on the capitalist economic system for their income and status in society. ${ }^{93}$ Immediately following his election, Allende instituted a large number of socialist economic reforms, including nationalizing the North American-owned copper industry, creating state-owned cooperative farms, and taking steps toward nationalizing other industrial sectors. Pursuant to this, Allende fixed prices on basic necessities and increased wages for labourers-the percentage of the national income going to labour grew from $55.0 \%$ to $65.7 \%$ in his first year of presidency. ${ }^{94}$ Workers liaised with government agencies to ensure working classes were represented in making policy decisions, and unions

\footnotetext{
${ }^{92}$ Gwynn Thomas, Contesting Legitimacy in Chile: Familial Ideals, Citizenship, and Political Struggle, 1970-1990 (University Park, PA: Pennsylvania University Press, 2011 ), 61.

${ }_{93}$ Lisa Baldez, Why Women Protest: Women's Movements in Chile (Cambridge: Cambridge University Press, 2002), 50.

${ }^{94}$ Thomas, Contesting Legitimacy in Chile, 93.
} 
were made more powerful, both in an effort to enfranchise workers. ${ }^{95}$

As expected, these changes, in addition to Allende's imposition of rationing on many consumer goods and his inability to deal with continued inflation, were met with great resistance by the middle and upper classes. ${ }^{96}$ Wealthy landowners whose farmland had been seized by the state felt they were inadequately reimbursed for the seizure. Bitter about the confiscations, the upper-class factory owners and businessmen began purposefully sabotaging production, resulting in more consumer goods shortages. ${ }^{97}$ Allende began bypassing congress entirely and making executive changes himself when the centrist Christian Democrats, whose support the UP had relied on in Chile's multi-party system, became increasingly unwilling to compromise. ${ }^{98}$

After a year during which Allende's opponents seemed paralyzed by indecision, a group of bourgeois women galvanized the opposition into action. ${ }^{99}$ On December 1 of 1971 they staged the "March of the Empty Pots and Pans" (or the Marcha de la Cacerolas Vacias) in downtown Santiago, so called because the women—many of them mothers—claimed they could not feed their children anymore. It was timed to coincide with the end of a three-week diplomatic visit by Fidel Castro, a visit that affirmed right-wing fears that Chile was on the path to

\footnotetext{
${ }^{95}$ Heidi Tinsman, Partners in Conflict: The Politics of Gender, Sexuality, and Labor in the Chilean Agrarian Reform, 1950-1973 (Durham, NC: Duke University Press, 2002), 210.

${ }^{96}$ Maria de Los Angeles Crummett, "El Poder Femenino: The mobilization of women against socialism in Chile," Latin American Perspectives 4, no. 4 (Autumn, 1977): 111.

${ }^{97}$ Baldez, Why Women Protest, 63-64.

${ }^{98}$ Thomas, Contesting Legitimacy in Chile, 94.

${ }^{99}$ Women had been particularly targeted by a scare campaign mounted against Allende by his political rival Jorge Alessandri during the 1970 election; ads imploring women to protect their families and children from the dangers of socialism and communism were popular, and Alessandri promised a significant female presence in government if elected. For more information see Why Women Protest (Baldez) and Right-Wing Women in Chile: Feminine Power and the Struggle Against Allende, 1964-1973 (Margaret Power).
} 
communism. ${ }^{100}$ Participants describe it as a spontaneous demonstration, an uncontrived, impromptu outpouring of frustration; however, there does seem to have been some forethought, for Silvia Alessandri (the niece of Allende's rival presidential hopeful Jorge Alessandri) had approached the Intendencia of Santiago on November $26,{ }^{101}$ asking them to waive the fees necessary to register the march, as the women were unsupported by any political parties and without a wealthy patron. ${ }^{102}$

An accurate count of the protesters who participated is difficult to ascertain, as numbers reported by left-wing media minimized them, while rightwing sources inflated them. The New York Times' number of 5000 is most frequently cited by international news media, though numbers used by Chilean opposition party members went as high as 200,000 . The March encountered resistance as it collided with a second, pro-government rally, and dissipated after violence broke out (each side blames the other for having initiated the violence). The women's march ended chaotically and prematurely, but they had very successfully and dramatically illustrated their potential as an activist political force. On December 2, 1971, the right-wing newspaper El Mercurio described the demonstration:

Yesterday afternoon the largest public demonstration ever, made up exclusively of women, took place in downtown Santiago. Tens of thousands of women of all ages congregated in the streets to protest food shortages and rising prices. As the crowd passed through the streets, women from the neighboring buildings showed their support and approval

\footnotetext{
${ }^{100}$ Baldez, Why Women Protest, 76

${ }^{101}$ A municipal administrative body.

102 The Intendencia agreed to waive the fee, but they also registered a counter-march by a progovernment group on the same day and at the same time, guaranteeing the two groups would cross paths (Baldez, 57).
} 
by leaning out of windows to clap, or to bang pots and pans. Chilean flags were put out. Shopping bags, cooking utensils, as well as pots and pans, made up the women's protest symbols. ${ }^{103}$

Soon, cacerolazos spread outside of the capital and became a popular method of protest in rural areas as well. For the next three years, until the military coup of 1973, numerous cacerolazos took place throughout Chile. ${ }^{104}$

\section{Results of the March}

The March had the effect of significantly changing the Chilean political landscape. The opposition to Allende realized that the open, confrontational nature of the protests was far more likely to result in overthrowing the Unidad Popular than political maneuvering in Parliament. Consequently, they switched their focus to supporting street demonstrations and rousing public protests, rather than engaging in the negotiations between opposition parties and talks with UP that had, so far, made little progress. ${ }^{105}$ The March also demanded that Chilean politicians view women as more than just voters, rather as potential political activists, able to campaign and mobilize opposition—something unheard of before.

Looking at the genesis of the cacerolazos in Chile, it is important to consider issues of gender as well as private/public space. The "casserole" was an object from the domestic, private space of the home, and was a symbol of nourishment, home, and care, associated with women and mothers. Chilean women were equated with mothers and their femininity was romanticized-rather

\footnotetext{
103 Quoted in Crummett, 104.

104 Crummett, 110.

105 Margaret Power, Right-Wing Women in Chile: Feminine Power and the Struggle Against Allende, 1964-1973, University Park, PA: Pennsylvania State University Press, 2003, 167.
} 
than struggle against these biased notions, right-wing activists embraced them for the value they had in marketing their cause. ${ }^{106}$ Given the women's roles as caretakers and guardians of the family, they were supposedly more insightful and prescient, able to use their "feminine intuition" and "maternal instincts" to foresee the dangers of Marxism. ${ }^{107}$ Stereotyped as homemakers by the rigid gender roles in the country at the time, Chilean women had never been seen as active in politics, and their public use of household objects was an appropriate symbol for their expanding role, from the domestic realm into the political sphere. ${ }^{108}$ Similar to charivari (see below), the pots and pans could be regarded as symbolic of the intermingling of the private and public spheres, by bringing domestic symbols out of the home and into the streets. ${ }^{109}$

In addition to marking the women's transition from the domestic realm into that of the public, the act of music-, sound- and noise-making was tied with feminist and political awakenings for the women involved; for many, the experience of partaking in anti-Allende protests empowered them at a time when women were still alienated from political discourse by both right- and left-wing

\footnotetext{
${ }^{106}$ Georgina Waylen, "Rethinking Women's Political Participation and Protest: Chile 1970-1990", Political Studies 40, No. 2 (1992): 308.

${ }^{107}$ Crummett, 110. During the 1970 federal election, both Allende and his competitor Allessandri ran campaigns based along gender-based assumptions: Allende capitalized on socialism's association with masculinity, in particular the image of the bold, visionary revolutionary fighter. In contrast, Chilean women were stereotypically tied with conservatism, and as such were the target of much of Allessandri's campaigning. The success of this campaigning was reflected in the results of the 1971 election, in which women voted for Allessandri over Allende by a margin of $7 \%$, while men voted for Allende over Allessandri by a margin of $10 \%$ (Margaret Power, Rightwing Women in Chile, 134-135, 138).

108 Waylen, 301.

${ }^{109}$ From a feminist perspective, the March of the Empty Pots and Pans poses an interesting contradiction, in which authority over the home that restrictive gender roles offered was ultimately helpful in empowering women in the larger political spectrum.
} 
political parties. ${ }^{110}$ One woman who was involved with the movement described her feelings thus: "We were important persons for the first time in our lives. We were tired of being treated like helpless, brainless individuals... we felt we had acquired independence; in this respect we can never go backwards." ${ }^{111}$ Krista Lynes describes the cacerolazo as a feminist language, "a persistent beat tied to the very heart of the personal as political."112

Overall, the March was a creative new way of demonstrating and organizing at a grassroots level, and it evolved into a recurrent protest method for Chileans. After Augusto Pinochet's coup on September 11, 1973, the pots and pans would not make an appearance for another ten years. In the climate of fear created by Pinochet's dictatorship, which was rife with disappearances, murder, torture, and illegal detentions, protest was generally stamped out before it even started. Along with many other free speech activities, singing in public was made illegal, stifling the nueva canción protest music that had been flourishing. ${ }^{113}$ Cacerolazos began to reappear in 1983, as labour organizers and activists searched for alternate methods of protest that would not provoke violent retaliation from the military. Every night at 8 p.m., Chileans would bang pots and pans for a period of time from within their homes. Where cacerolazos began as a bold statement, they were resurrected in 1983 as a subtler, less confrontational move, a low-risk and accessible protest that promoted solidarity and collective

\footnotetext{
${ }^{110}$ Pinochet, Allende, and Alessandri were all in agreement that women were most valuable to the state as wives and mothers (see Waylen, Chaney, and Power).

${ }^{111}$ Quoted in Crummett, 112.

${ }^{112}$ Krista Lynes, "Clamouring out: Against the Privative Sphere," Wi: Journal of Mobile Media 6, No. 3 (June 2012), http://wi.mobilities.ca/clamouring-out-against-the-privative-sphere/.

${ }^{113}$ Daniel Party, "Beyond 'Protest Song': Popular Music in Pinochet's Chile (1973-1990)," in Music and Dictatorship in Europe and Latin America, ed. Roberto Illiano and Massimiliano Sala,(Turnhout, NL: Brepols Publishers, 2012), 671-672.
} 
action. In the 1980s they acted as a small first step in building the confidence needed to openly oppose the dictatorship, showing the flexibility of cacerolazos as a form of protest. ${ }^{114}$

Since its appearance in Chile, the tactic has spread widely. Uruguayans used pots and pans to protest during early 1980s against a military dictatorship that prolonged and stalled the transition to democracy. ${ }^{115}$ In Argentina cacerolazos were staged during the economic crisis of 2001, beginning in Buenos Aires but spreading all over the country. ${ }^{116}$ The women of Oaxaca, Mexican protesters mounted cacerolazos in 2006, during a teacher's strike that gained support from other unions and grassroots organizations. ${ }^{117}$ As recently as 2013, they spread into Colombia, where rural labourers used pots and pans to protest free trade agreements and privatization. ${ }^{118}$ In Chile, as in Montréal, a student movement began in 2011, protesting a privatized education system that is the legacy of Pinochet's dictatorship and often using cacerolazos to do so. Staging a comeback during the Chilean federal elections in 2013 after a year of relative quiet, the student marches have been by far the largest protests since the end of the dictatorship, enjoying considerable popular support-four student leaders, including Camila Vallejo (see page 14) were elected to Parliament

\footnotetext{
${ }^{114}$ Goerge de Lama, "Chile Marches Toward Freedom to the Beat of Pots and Pans," Chicago Tribune, September 11, 1988, http://articles.chicagotribune.com/1988-09-11/news/8801290837_1_post-pinochetchilean-military-regime.

${ }^{115}$ Martin Renauld, "A short history of cacerolazos," Daily Gumboot, June 20, 2012. http://dailygumboot.ca/2012/06/a-short-history-of-cacerolazos/.

${ }^{116}$ Andrew Loewen, "From Cacerolazo to Casseroles, From the Kitchen to the Streets,"Palty Sapien, May 27, 2012, http://www.thepaltrysapien.com/2012/05/from-cacerolazo-to-casserolesfrom-the-kitchen-to-the-streets/\#sthash.HLo3JtL8.dpuf.

117 "Q\&A Crisis in Oaxaca," BBC, October 31, 2006, http://news.bbc.co.uk/2/hi/6102018.stm.

${ }^{118}$ Sarah Lazare, "Colombia Nationwide strike against 'Free Trade', Privatization, Poverty," Common Dreams, August 25, 2013, https://www.commondreams.org/headline/2013/08/25.
} 
during the December federal elections, and their term began in March of $2014 .^{119}$ The demonstrations were highly organized, sometimes involving extensive use of music and choreography. The casseroles-turned-instruments made many appearances throughout the protests, and the protesters often found their performances accepted and augmented by residents joining in from porches and balconies, even in the very same conservative neighbourhoods where the cacerolazos were first heard 40 years earlier. ${ }^{120}$

It may initially appear that the casseroles themselves are hindered by their lack of language; its development in Chile show us how easily it was appropriated by the left in spite of its right-wing origins. However, this very wordlessness has also helped allow the tactic to become so pervasive, since it is not tied to a particular cause or language, which is an argument often made about the power of music. The common thread between these causes is that, while they have embraced a wordless and voiceless protest tactic, participants are often the disenfranchised, those whose voices or words are discounted or devalued by hegemonic discourses. McGill Communications professor Darin Barney writes of the protesters, "These are not people without voice, they are just people who have finally decided to use their voice. While they might not be using words, the form of their action is speech-like in that they are recognizable as subjects and as potential parties to a conversation." 121

\footnotetext{
119 Jonathan Franklin, Four Chilean Student Leaders Make the Jump to Parliament," Truthout, 18 November 2013, http://truth-out.org/news/item/20114-4-chilean-student-leaders-make-the-jumpto-parliament.

${ }^{120}$ Sergio Villalobos-Ruminott, "The Chilean Winter," Radical Philosophy 171 (2012): 11-15, http://www.radicalphilosophy.com/commentary/the-chilean-winter.

${ }^{121}$ Darin Barney, "The Truth of Le Printemps Érables," Theory and Event 15, 3 (2012). doi: http://10.1353/tae.2012.0054.
} 
The idea that the voice is equated to agency and democracy, and that vocality can be a vehicle for empowerment, is prevalent in Western thought and philosophy. ${ }^{122}$ Similarly, the voice has become a master trope for a person's identity and "essence," in part because of its role in bridging the interiority and exteriority of a person. ${ }^{123}$ Both of these metaphors have become pervasive as the result of individualist, rationalist post-Enlightenment thinking. However, ethnomusicologist Martin Daughtry feels that they are flawed metaphors, as the absence of the voice does not always forestall empowerment. ${ }^{124}$ In this way, the voicelessness of a cacerolazo should not be mistaken for muteness; rather, it is a way of breaking imposed silences and forcing public discourse on political issues. The casseroles are used to strengthen voices that might otherwise have been lost or drowned out - the voices of youth, women, the poor, the families of los desasparicidos, ${ }^{125}$ as the case may be.

\footnotetext{
${ }^{122}$ Martin J. Daughtry, "From Voice to Violence and Back," in Music, Politics, and Violence, eds. Susan Fast and Kip Pegley (Middletown, CT: Wesleyan University Press, 2012), 250.

${ }^{123}$ Daughtry, 248.

${ }_{124}^{124}$ Daughtry, 252.

${ }^{125}$ Spanish for "the disappeared," this was the title given to victims of Pinochet and the Uruguayan civic-military dictatorship, who were secretly abducted and then imprisoned, tortured, or murdered.
} 


\section{Charivari}

\section{Charivari in Medieval Europe}

The word charivari comes from the $14^{\text {th }}$ century Old French chalivali, defined as "discordant noise made by pots and pans," which is in turn usually identified as a descendent of the Greek karēbaria, meaning headache or heavy head. ${ }^{126}$ The word charivari has come to signify a noisy procession playing pots and pans in both French and English languages, though in English the name is sometimes shortened to chivari or chivaree. ${ }^{127}$ Like cacerolazos, charivaris involved the use of pots and pans as a communal expression of dissent; however, unlike cacerolazos, they were not related to political grievances but rather personal ones, at least at first. Charivaris generally occurred when a person or household had offended their community's values in some way. Usually led by a communities youth, townspeople would select a target who had behaved in a way that was judged unseemly or improper, and set about deterring these behaviours. ${ }^{128}$

The target's household would be subjected at night to a discordant, parodic serenade of pots, pans, cauldrons, tongs, casseroles, and other kitchenware that publically ridiculed the homeowner(s) for their indiscretions. Masked and often wearing costumes, participants walked or rode donkeys while announcing the guilty party's indiscretions to bystanders, throwing or breaking

\footnotetext{
${ }^{126}$ Online Etymology Dictionary.

http://www.etymonline.com/index.php?allowed_in_frame=0\&search=charivari\&searchmode=none

${ }^{127}$ While cacerolazos is a Spanish word without an English equivalent, the word charivari has been adopted into the English language from its French roots-hence the word remains in regular font (rather than italicized) throughout this thesis.

${ }^{128}$ E. P. Thompson, Customs in Common: Studies in Traditional Popular Culture (New York: New Press, 1992), 469.
} 
items, and causing general mayhem. ${ }^{129}$ The cacophonous parade might repeat itself for several consecutive nights, winding through town to end at the target's home, accompanied by shouted insults, song, dance, and drinking. ${ }^{130}$ While similar traditions existed all over Europe (such as Katzenmusiken in Germany, "rough music" in England, or sharivari in Rumania), I will be looking at the charivari in France, where the tradition continued into the mid-twentieth century in some rural areas and whose custom seemed most influential for Québec practices. $^{131}$

The causes of charivari and moods behind their intent varied quite widely. Sometimes it was a celebratory event-for example, a charivari was often used as a spirited sending off for a newlywed couple into married life on the night of their wedding. ${ }^{132}$ Most often, however, it was employed to remonstrate sexual behaviour that was perceived as improper by the community. Charivari was frequently used to force unmarried couples to wed, to express displeasure with an adulterer or a woman who remarried too soon after her husband's death, or to express opposition to the marriage of a younger woman to a much older man. Charivaris might also be directed at brides who were pregnant at marriage, or who had turned down a particularly popular bachelor from the community in favour of someone less well regarded. ${ }^{133}$ On some occasions it was used to shame abusive spouses or parents, both male and female. The charivari was a

\footnotetext{
${ }^{129}$ Emma Dillon, The Sense of Sound: Musical Meaning in France, 1260-1330 (New York: Oxford University Press, 2012), 93.

${ }^{130}$ Loretta T. Johnson, "Charivari/Shivaree: A European Folk Ritual on the American Plains," Journal of Interdisciplinary History 20, no. 3 (1990), 372

${ }^{131}$ Alford, 513.

132 Johnson, 372; Alford, 516.

133 Johnson, 377.
} 
practice in both rural and urban France, and the nobility, bourgeoisie, and lower classes were all targeted indiscriminately, though the nobility had more resources with which they could manipulate the situation to their advantage (for example, by bribing the revelers into leaving).

Charivaris can be seen as method of channeling and controlling hostility, preventing outbreaks of physical violence. In his book Customs in Common: Studies in Traditional Popular Culture, E. P. Thompson claims that while the noise of charivaris represented symbolic violence, the structured nature of the ritual promoted order and stability; on those occasions in which physical violence occurred, it was the result of the breakdown of ritual control. ${ }^{134}$ Historian John Cashmere feels differently, however. After recounting several incidences in which charivari turned violent in $17^{\text {th }}$ century France, Cashmere states that charivaris "were never intended to be purely hearty folk rituals or harmless diversions. They were contests, often punitive ones, and, for the victims at least, distinctly uncomfortable and unpleasant experiences." ${ }^{135}$ Cashmere recounts several occasions when violence broke out during charivaris, including an incident in St-Rambert-sur-Loire in 1642 that resulted in the beating and physical assault of a young couple targeted by a charivari. ${ }^{136}$ While the physical assault of the targets was rare, on some occasions charivari took on a more threatening tone, accompanied by effigies of the targeted widow's dead spouse or by the

\footnotetext{
${ }^{134}$ Thompson, 485.

135 John Cashmere, "The Social Uses of Violence in Ritual: Charivari or Religious Persecution?" European History Quarterly 21 (1991): 313.

${ }^{136}$ Cashmere, 294-296.
} 
splattering of animal blood on doorsteps. ${ }^{137}$ In some such documented cases, the target, feeling enraged or threatened by the charivari, opened fire on the revelers, causing injury. ${ }^{138}$

In contrast with Cashmere's view of charivari as an aggressive and destructive intrusion into the personal lives of those subjected to it, a number of scholars believe that the charivari acted as a form of symbolic acceptance of a social transition; ${ }^{139}$ a community would use the ritual to express reluctant acknowledgement of a change in social status (such as through marriage). The disorder of the music represented the chaos of the transition from old to new, with the disruption to the social order echoed by the disruptiveness of the ritual; Palmer notes that the police disliked charivaris because they "frequently rendered the roads impassable." ${ }^{\prime 40}$ They were a rite of passage that expedited the process of social change, while reminding individuals that they were subject to the community's judgment. Since youths were the primary instigators, it was also a way that young community members could express themselves in a highly ordered, hierarchical society. ${ }^{141}$ Johnson reminds readers that the charivari served to protest events that the community did not truly expect to prevent. Most of the marriages protested, for example, would already have taken place, and therefore, the charivari's participants would have known they had no hope of

\footnotetext{
137 Johnson, 375.

${ }^{138}$ Alford, 510.

${ }^{139}$ For example, historian E. P. Thompson Customs in Common: Studies in Traditional Popular Culture (New York: New Press, 1992), and medieval historian Claude Gauvard and anthropologist Altan Gokalp in "Les Conduites de Bruit et leur Signification a la Fin du Moyen Age: Le Charivari." Annales, Histoire, Sciences Sociales 29, No. 3 (1974).

${ }^{140}$ Bryan D. Palmer, "Discordant Music: Charivaris and Whitecapping in Nineteenth-Century North America," Labour / Le Travail 3 (1978): 11.

${ }^{141}$ Claude Gauvard and Altan Gokalp. "Les Conduites de Bruit et leur Signification a la Fin du Moyen Age: Le Charivari.” Annales, Histoire, Sciences Sociales 29, No. 3 (1974): 703.
} 
stopping or dissolving them. ${ }^{142}$ In this sense, they were not a mechanism for true social change but rather a symbolic gesture. ${ }^{143}$

Most accounts describe a cacophony of sound, creating an "overwhelming and abrasive soundscape" that could likely be heard from as far as two miles away. ${ }^{144}$ Percussive, non-pitched instruments were created out of any farm or household object on hand, including basins, kettles, pans, bones, whistles, cattle horns, and bells. ${ }^{145}$ These were instruments that could be assembled easily, were portable, and "played without technique, in a derisive style." ${ }^{146}$ Rocco Coronato sees the chaos of the charivari as "acoustically reproducing the jarring disharmony inflicted by such eccentric marriages to the social body," reflecting the "grotesque" in an act seen as violating shared social norms. ${ }^{147}$ The revelers were echoing the subversion and disorder that they saw in the original act, an "ordered representation of disorder."

The demonstrators used vocalization, body percussion, and whistling to add to the clamor. Mocking songs were sometimes aimed at the targets, but more often descriptions of charivari emphasize shouting, screaming, booing, and hissing. ${ }^{149}$ Musicologist Emma Dillon describes the way charivaris challenge our perception of music, as sound that "hover[s] at the fringes of the singing voice.

\footnotetext{
142 Johnson 1990, 379.

${ }^{143}$ It would be later, during the Lower Canadian Rebellion, that this would start to happen-see pages 57-59.

144 Dillon, 97; Palmer, 12.

${ }_{145}$ Palmer, 11.

${ }^{146}$ Peignot, quoted in Jean-François Robic, Représentation et politique (Paris: L'Harmmattan, 2010), 101.

${ }^{147}$ Rocco Coronato, Jonson Versus Bakhtin: Carnival and the Grotesque,(Amsterdam: Rodopi Bv Editions, 2003), 89.

${ }^{148}$ Eugene Vance, "Le Jeu de la feuillée and the Poetics of Charivari," MLN 100, No. 4 (September 1985): 817, http://www.jstor.org/stable/2905483.

${ }_{449}$ Dillon, 98.
} 
Neither speech nor song, voices taunt the official categories of verbal and musical communication." ${ }^{150}$

\section{Charivari in Québec/Lower Canada}

The first documented appearances of charivari in North America took place in Lower Canada during the late $17^{\text {th }}$ century, though charivari would later take place in Alabama, the French-speaking colonies of Louisiana, and would eventually spread to English-speaking areas. ${ }^{151}$ The North American version of charivari was remarkably consistent in structure, purpose, and atmosphere with its European counterparts, although historian Loretta Johnson contends that they were less violent and extreme. Some of the more violent behaviours that accompanied charivari in France—-the blood splattering and effigies described earlier-never materialized in Lower Canada. ${ }^{152}$ On occasions where charivari threatened to turn violent, a mediator would be called upon to negotiate between the targets and participants. The beleaguered person usually offered monetary compensation to the demonstrators as compensation for his or her alleged indiscretions, resulting in a peaceful resolution.

The only other significant difference between the French and FrenchCanadian charivari was that French-Canadians practiced charivari almost exclusively in response to socially mismatched marriages. Since the charivari was so often directed specifically at newlyweds in French Canada, Allan Greer theorizes that it was not just simply a charge of immorality on the part of the

\footnotetext{
150 Dillon, 96.

151 Palmer, 17.

152 Johnson, 380.
} 
accused, but a public chastisement of the church. ${ }^{153}$ The Roman Catholic church had a powerful influence on the lives of French-Canadians, and while the clergy were supposed to be responsible for upholding the sanctity of marriage, in practice they could not refuse to marry a couple even if they were suspected of having sinful motives or behaviours. The Church was generally an outspoken opponent of charivari, perceiving that by casting aspersions on the morality of unions that had been sanctified by the church, the community was also implicitly criticizing the church. Thus, in French Canada, the performance of charivari evolved to incorporate an anti-authority subtext. ${ }^{154}$

Understanding this subtext, the church condemned charivaris as undignified and deleterious, forbidding the faithful from being involved with them in any way. From the very earliest appearances of charivari, such as the case of a Québec woman who was the subject of a demonstration in June, 1683, evidence can be found of the hostility they elicited from the established authorities of church and state. ${ }^{155}$ In the early $19^{\text {th }}$ century, La Prairie priest JeanBaptiste Bouchard waged a furious war from his pulpit against the charivari, threatening to cancel church events if the practice were not stopped. His parishioners refused, and the custom took on an overtly anti-clerical tone as participants added mock sermons and funeral processions to the evening's entertainment. Bouchard was eventually forced to admit defeat and the charivaris

\footnotetext{
153 Greer.1990, 30.

154 Greer 1993, 82.

155 Palmer, 17-18. The woman in question remarried 21 days after her husband's death, an unseemly short period of time by the standards of her community. The people of Québec conducted charivaris every night for a week, provoking sharp disapproval from the local Bishop François de Laval, who threatened the participants with excommunication.
} 
of La Prairie continued unabated. ${ }^{156}$ It was not just the church that struggled against the custom: demonstrations were so frequent in Montréal during the 1820s that an edict from the police was issued, implementing fines for masked revelers who disturbed the peace of the city and suburbs with the noise of "pots, chaudières, cornes ou autrement" (pots, kettles, horns, and similar implements). ${ }^{157}$ In these examples, we see the power this predecessor of les casseroles possessed over government and church policy, and the beginnings of the tactic's dissident leanings.

Though not overtly political, charivaris represented an extra-legal mechanism of community control and protest, outside the authority of the state and the church. As such, they were perceived as a threat to the existing social order by these institutions. The music itself reflected a subversive tenor: Robic describes the act of performing charivari as "musicales anarchiques," a word choice that emphasizes its place in opposition to institutions of law and order. ${ }^{158}$ As noted earlier, charivaris exist somewhere between the boundaries of song and speech; they are situated within other boundaries as well, exposing "areas of expressive transgression in music, particularly around the boundaries of generic category, words and music, singing and speaking, and sense and sound."159 The challenge charivaris presented to authority was cemented during the Lower Canada Rebellion of 1837 , when it suddenly and quite dramatically transformed from a fairly benign folk ritual into a powerful form of political

\footnotetext{
${ }^{156}$ Allan Greer, The Patriots and the People: The Rebellion of 1837 in Rural Lower Canada, (Toronto: University of Toronto Press, 1993): 83.

157 Palmer, 19.

158 Robic, 102.

${ }^{159}$ Dillon, 97.
} 
protest. ${ }^{160}$ Political conflict between the French-Canadian Patriot Party (or Patriotes) and their British-backed coalition of opponents had been escalating since the 1820 s as the former tried to limit the power of the British governor and instate responsible government. While the Patriot Party controlled the provincial legislative assembly due to its popular support, they were effectively stalled by the British coalition, which controlled the non-elective legislative branches. ${ }^{161}$ When the imperial government denied Patriot demands for constitutional reform in 1837 , protest broke out. It was during that summer that the first political charivaris took place, used to repress individuals suspected of favouring the colonial regime. Demonstrations labeled charivaris by both the perpetrators and targets began in August of 1837 , and they would play an important role in mobilizing popular Patriot support in the months leading up to the open rebellion that began in November. ${ }^{162}$

Public figures, particularly militiamen and magistrates, who supported the British were especially targeted, with the charivari ending in demands for the official's resignation rather than monetary compensation. ${ }^{163}$ The charivari was sometimes accompanied by vandalism, particularly the cutting down of the maypole that was presented to a Captain when he was appointed to his rank, in a symbolic revocation of his post. When Loyalist officers resisted calls for resignation, the charivaris intensified and became increasingly threatening. As an accompaniment to the performance of the charivari itself, aggressors threw

\footnotetext{
${ }^{160}$ Allan Greer, "From Folklore to Revolution: Charivaris and the Lower Canada Rebellion of 1837," Social History 15, no. 1 (1990): 34.

${ }_{161}$ Greer 1990, 34.

162 Greer 1990, 35.

163 Greer 1993, 200.
} 
stones and launched other missiles into homes, broke windows and damaged roofs, and even attempted arson on several occasions. However, while there was considerable damage to property, relatively few injuries resulted, despite the escalation towards more violent rebellion that was taking place. ${ }^{164}$

In particular, Montréal was the scene of a large number of charivaris due to the proliferation of Patriot sympathizers in positions of power. They were so effective in shaming government officials into resigning that by mid-November, when the armed rebellion began, there was virtually no government presence in the rural parishes of the Montréal District. ${ }^{165}$ In general, charivari provided a structure within which collective action could be taken, a structure that assisted French-Canadians in mobilizing and organizing at a time when they lacked institutions or groups to coordinate resistance efforts. An undertaking that was more musical and social than militaristic, the charivari acted as a method of channeling a mob's hostility with diminished risk violent outbreaks. However, while rarely violent themselves, they were extremely successful in transforming popular sentiment into action, and played a role in cultivating support for what would become an open rebellion. ${ }^{166}$

\footnotetext{
${ }^{164}$ Greer 1990, 38-39.

165 Greer, 1990, 41.

${ }^{166}$ Albeit an open rebellion that would be crushed soon after it started. The Patriot rebels were poorly trained and organized, while their opponents included trained British soldiers; the rebellion was short-lived. A year later in November, a second rebellion would be similarly quashed. P.A. Buckner, "Rebellions of 1837," Canadian Encyclopedia July 15, 2013, http://www.thecanadianencyclopedia.com/en/article/rebellions-of-1837/.
} 


\section{Connecting cacerolazos, charivaris, and les casseroles}

\section{Similarities with les manifestations casseroles}

The casserole was a symbol that caught on during the anti-Allende protests, and was made into pins that could be worn at all times to show support of the movement. ${ }^{167}$ These pins are reminiscent of the red squares that supporters attached to their clothing in support of the student movement. The image of a casserole adorned the cover of right-wing Chilean newspaper $L a$ Tribuna for a month after the "March of the Empty Pots and Pans." 168 Similarly, in Uruguay, a women's movement advocating a transition to democratic government called their newspaper La Cacerola, in reference to "protests when the streets resonated with the sound of casseroles being beaten with spoons... A resistance spontaneous and collective, made with casserole in hand." ${ }^{169} \mathrm{La}$ Cacerola describes the image as being a "symbol of national liberation" that they believe nearly all Uruguayans would recognize, and thus it depicted a casserole boiling over on the cover of its publications. As previously noted, reporting the day after the "March of the Empty Pots and Pans," newspaper El Mercurio almost immediately identified the casserole as symbolically representing the movement: "Shopping bags, cooking utensils, as well as pots and pans, made up the women's protest symbols."

\footnotetext{
${ }^{167}$ Power, Right-Wing Women in Chile, 166.

${ }^{168}$ Power, Right-Wing Women in Chile, 166.

${ }^{169}$ Francesca Miller, Latin American Women and the Search for Social Justice (Hanover, NH: University Press of New England, 1991): 225-226.

170 Quoted in Maria de Los Angeles Crummett, "El Poder Femenino: The mobilization of women against socialism in Chile," Latin American Perspectives 4, no. 4 (Autumn, 1977): 104.
} 
The image of the casserole was also adopted by many of the student and academic publications that came out during the Montréal protests. One such example can be found on the cover of Academic Matters Journal of Higher Education for its November, 2012 edition:

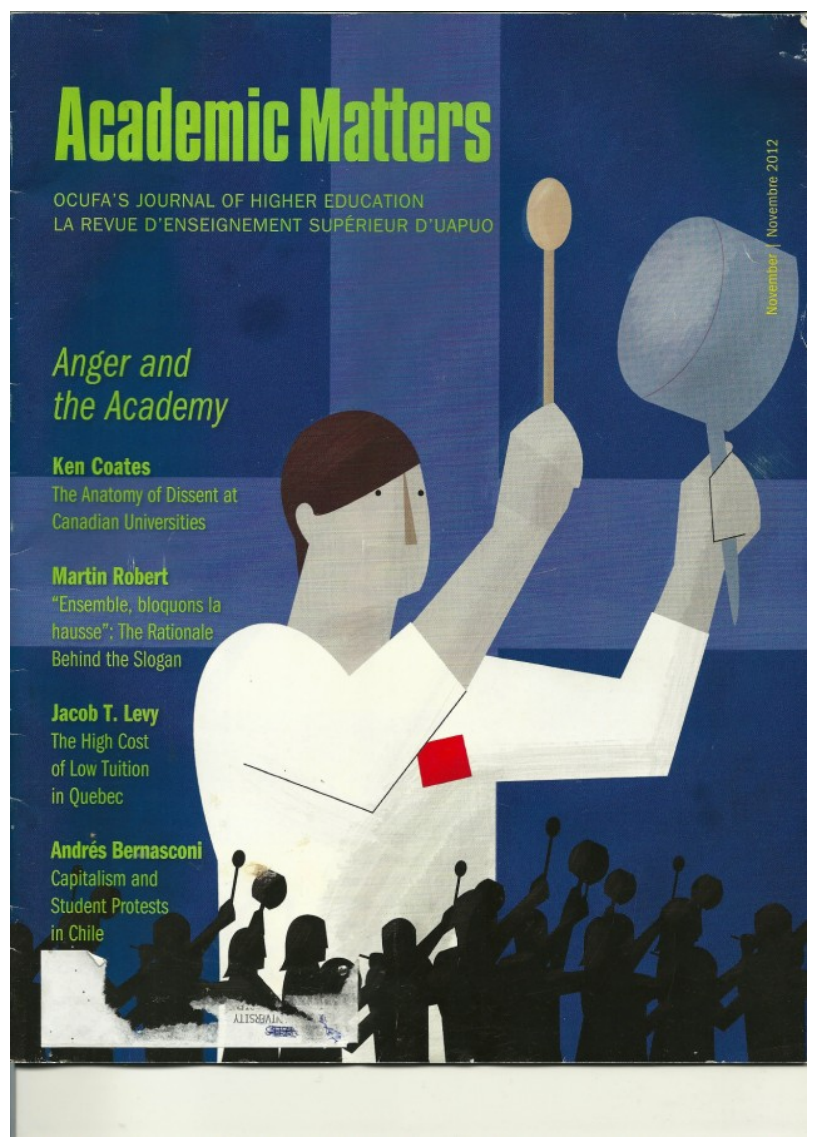

A magazine dedicated to exploring issues of significance to higher education in Ontario, Canada, it contains articles exploring the pros and cons of the tuition hike, with articles both supportive and critical of the general student movement. ${ }^{171}$ The cover illustration by Marie-Claude Carignan depicts a generic protester, whose unclear features, androgynous gender and blank, unremarkable dress position him/her as a vehicle for the important symbols: the red square and the

${ }^{171}$ Academic Matters Journal of Higher Education, November 2012. 
casserole. Especially interesting is the artist's decision to remove the protester's mouth, a literal representation of the "voicelessness" of les casseroles discussed earlier. Yet the sonic element of the casseroles is made clear through the illustration-each protester, including those silhouetted at the bottom, are depicted mid-strike.

Another example is the following image, featured in a special issue of $\mathrm{Wi}$ Mobilities, focusing on the Quebec student protests:

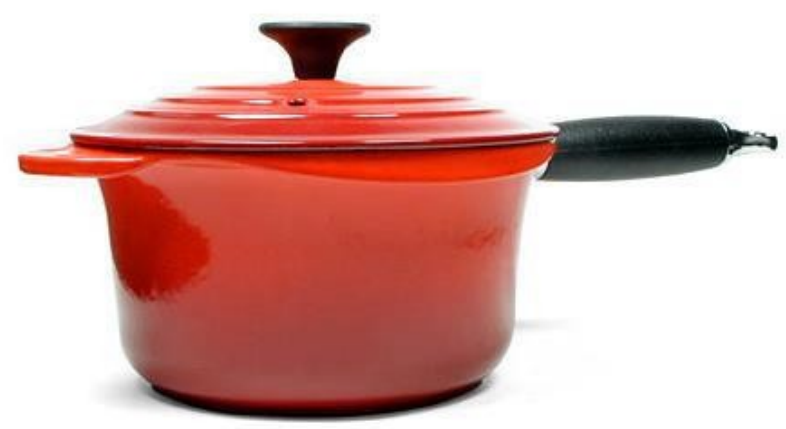

This machine kills fascists.

Image featured in Wi Mobilities

In this case, the casserole is bright red, recalling the commonly worn red squares that also symbolized the movement. ${ }^{172}$ The words "This machine kills fascists" are those of Woody Guthrie, the American folk musician who rose to fame in the Depression era for his protest music. Guthrie had these words inscribed on his

\footnotetext{
172 Joseph Rosen, "Multigenerational Casserole Orchestras: The New Face of Anarchist Insurgency," Wi Journal of Mobile Media Special Issue (2012), http://wi.mobilities.ca/multigenerational-casserole-orchestras-the-new-face-of-anarchistinsurgency/. Image by Anna from Translating Le Printemps Érables.
} 
guitar, inspiring similar inscriptions by other left-leaning musicians in the future. ${ }^{173}$ In this case, the casserole is being equated with the musical instrument (Guthrie's guitar), and the sound it creates with protest music. By drawing this connection to Guthrie, the visual image emphasizes the aurality and musicality of les casseroles as a method of crafting protest.

These are just two examples from a plethora of casserole depictions created during and in the time surrounding the protests in Québec. In the case of the two images just introduced, the content of the journals was not centered explicitly on les manifs casseroles, but the larger student movement. This is indicative of a larger trend: the image of the casserole is emblematic not just for les manifs but the student movement as a whole, whereby it has been incorporated into a larger context (canon) of protest symbols. As was the case in Uruguay and Chile, the struck casserole connotes dissidence and rebellion, in addition to representing specific protest movements.

Unlike the red square, the casserole was a symbol that had a sonic identifier as well as a visual one; the sound of the casseroles came to signify defiance. It is a common, mundane sound-associated with kitchens, cooking, daily living—repurposed for political and musical intents. It could be said to represent a democratization of protest sound, since it enables anyone to contribute to the din. Writing about charivari, Greer describes pots-and-pans demonstrations as "a sort of 'people power' of the street... It was, then, 'democratic' in a literal sense. This was a combative democracy, one which had

\footnotetext{
${ }^{173}$ Pete Seeger, for example, wrote the phrase "This Machine Surrounds Hate and Forces It to Surrender" on his banjo. Riley Henderson Maynard, "Protest music lyrics, 1962-1975" (PhD Diss., St. Louis University, 1995), 8.
} 
to be defended against the repressive measures of officialdom. It was

nevertheless a subordinate democracy, an exercise of popular power..."174

The charivari represents the morals and ideals of those participating; it was a tool of the populace for self-regulation, and taking justice and punishment into their own hands, for better or for worse. It acted as "a public naming of what [had] been named before only in private," making the appropriation of domestic objects—such as pots and pans—particularly symbolic in public life. ${ }^{175}$

Cacerolazos functioned similarly, taking the symbol from the "private space, the hearth," and bringing it out onto the street. ${ }^{176}$

Charivaris and les manifs casseroles formed very public critiques of existing power structures, though with variable success in dismantling them. Charivaris have been interpreted with reference to Mikhail Bakhtin's understanding of carnival—-that is, a ritualistic spectacle that involved the inversion of social norms and values. ${ }^{177}$ Bakhtin discusses charivari as an expression of dissent towards authority and an assertion of power/identity, fitting in with his idea that carnival challenges existing hierarchies, though generally only temporarily. ${ }^{178}$ He notes that a description of charivari from the Roman de Fauvel depicts participants as wearing masks, costumes, and turning their clothing backwards, presenting an image of the sort of backwardness and social defiance that carnival represents. Similarly, Monréal protesters were frequently

\footnotetext{
174 Greer 1990, 34.

175 Thompson, 488.

176 Miller, 226.

${ }^{177}$ For more information, see Mikhail Bakhtin's Rabelais and His World, trans. by Hélène Iswolsky (Bloomington, IN: Indiana University Press, 1984).

${ }_{778}$ As Coronato writes, "yet we might see in both theatrical and carnivalesque inversion a temporary enactment of the word-upside-down which only reinforces the traditional order," (88).
} 
masked or costumed, the most famous example being "Anarchopanda," a philosophy professor in a panda suit who spent the demonstrations dancing with protesters and offering hugs to police. ${ }^{179}$ Wearing clothing backwards or inside out is a less obvious inversion of norms in modern-day Montréal; however, the nude protests that took place during les casseroles could be viewed as playing a similar role with a contemporary, more overt reversal of social norms. Aside from the dress of students, the casseroles themselves are "carnival objects"-objects that "are, so to speak, turned inside out, utilized in the wrong way, contrary to their common use. Household objects are turned into arms, kitchen utensils and dishes become musical instruments." 180

The ideas of carnival and spectacle can similarly enrich our understanding of les casseroles, as well as many of the other protest movements in recent years. Writer and curator Claire Tancons observes that "the carnivalesque-as a medium of emancipation and a catalyst for civil disobedience-is alive and well, and these contemporary carnivals have retained their rebellious potential." ${ }^{181}$ It seems that these carnivalesque traits, particularly the use of masks, costumes, and carnival objects and anti-authority impulses, are consistent between charivaris and les manifs casseroles. Given these similarities, it stands to reason that les manifs casseroles, like many carnivalesque performances, offered a temporary upheaval of socio-political hierarchies. In addition to acting as a

\footnotetext{
179 "Grève étudiante: un panda pour la gratuité scolaire," Huffington Post Québec, May 15, 2012. http://quebec.huffingtonpost.ca/2012/05/15/panda-gratuite-scolaire_n_1519899.html.

${ }^{180}$ Mikhail Bakhtin, Rabelais and His World, trans. by Hélène Iswolsky (Bloomington, IN: Indiana University Press, 1984), 411.

${ }^{181}$ Claire Tancons, "Occupy Wall Street: Carnival Against Capital? Carnivalesque as Protest Sensibility," e-flux 30 (December 2011), http://www.e-flux.com/journal/occupy-wall-street-carnivalagainst-capital-carnivalesque-as-protest-sensibility/.
} 
method of envoicing and communicating dissent, it also afforded relief from the status quo and "celebrated temporary liberation from the prevailing truth of the established order." ${ }^{182}$

Through charivari, citizens could reclaim power from authority figures whom they perceived as having failed to represent their best interests. In many of these ways, les manifs casseroles did not drift far from their roots in charivaris. In this case, the moral convictions of one group of the populace (the students) were not in line with those of the authority figures of the government. ${ }^{183}$ As the charivaris were once used to shame individuals, the protesters deployed les manifs casseroles to shame the government. The Québec protests embraced the audible tradition not only as a mechanism for protest, but as an accusatory rebuke of those who did not hold the same beliefs as them, in keeping with the ritual's original intention.

The police of 2011 did not react so differently from the police of almost two centuries ago in French Canada: they threatened demonstrators with fines and opposed the use of disguises to mask identity. Greer's defense of charivaris could be applied equally to the Québec protests: "Far from being spontaneous or anarchic, these were fairly organized demonstrations, carefully prepared in

\footnotetext{
182 Bakhtin 1968, 10. Some of the many existing examples of work in this area include Baz Kershaw's The Politics of Performance: Radical Theatre as Cultural Intervention (New York, NY: Routledge,1992), Chapter 3 of which focuses on carnival as a strategy by alternative theatre to "resist incorporation into the status quo" (69), and a variety of examples from Carnival: Culture in Action - The Trinidad Experience edited by Milla Cozart Riggio (New York, Ny: Routledge, 2004). ${ }^{183}$ In both the case of the charivaris and les manifs casseroles, aspersions have been cast on the motives of protestors/revelers. Crane writes that youth involved in charivaris were mainly interested in having an arena for outrageous, aggressive behaviour. The casserole protests have been labeled as self-interested behaviour of students wishing to place the burden of paying for education on others rather than accept it themselves. Thus, the idea that "moral convictions" were the cause of both events is arguable.
} 
advance. More to the point, charivaris, though filled with bluffs and threats to their targets, were quite restrained. Real violence occurred only when the crowd came under actual attack." ${ }^{184} \mathrm{He}$ argues that it was not until either the police (or in some cases, the newlywed couple) attempted to suppress the charivari that riots and violence would break out. The student protests were similarly characterized as being riotous and unruly, but in reality, were generally peaceful and orderly, and turned violent only on rare occasions. ${ }^{185}$ Bourdeleau describes the disjunction between the chaos portrayed in the media and the experiences of the marchers, who felt they were part of a highly organized group united under a shared purpose. Violence and disorder happened only when the police assaulted the crowd, he claims. ${ }^{186}$

\section{Musicality}

One might imagine that les manifs casseroles were musically similar to charivaris and cacerolazos (though in the absence of recorded evidence of charivaris this is purely speculative). ${ }^{187}$ In all three examples, the volume of the instruments seems to be generally acknowledged as its most notable feature. Protestors within les manifs report that the sheer power of the volume was often overwhelming; many of them wore earplugs to soften the noise. The sounds of the pots and pans tend to be loud, sharp, and short, decaying quickly—the

\footnotetext{
${ }^{184}$ Greer 1990, 33.

185 Sterne, 2012.

${ }^{186}$ Érik Bordeleau, "Intuition Première: La Force étrange du Printemps Québécois," Theory and Event 15, 3 (2012), doi:10.1353/tae.2012.0062.

${ }^{187}$ As of yet in my research I have been unable to locate any recordings of charivari, which have been practiced infrequently in the past 100 years.
} 
"transient (the sharp, initial part of the hit) can be piercing at close range due to frequencies at the very top of the audible range traveling at a high sound pressure level." ${ }^{188}$ From outside the manif the sound is dulled considerably, but still highly audible — writings from medieval times indicate the charivaris could be heard from great distances away, and though located in a different urban soundscape, the sound of manifs casseroles have been known to carry similarly across neighbourhoods. Jonathan Sterne sees this volume as a feature of the music that helps drive home the purpose of les manifs casseroles: "Since the point of the protests is to audibly flout Law 78 , the fact that they can be heard much further than they can be seen helps make this lawbreaking an expressly public and political act." 189

The pots and pans selected often reflected the desire for volume; Caroline Echeverria reported that aluminum pots were most commonly used because it was found to be the loudest, most reverberant material. ${ }^{190}$ Most protesters used pots, frying pans, or pot lids, with some striking baking sheets, bowls, or water bottles. While some of them chose to bang two pots and pans together, like cymbals, wooden spoons were the kitchen implements of choice for making the sounds. Metallic utensils were used less frequently, possibly because they carried a greater risk of damaging the pot or pan. More unusual selections included whisks, spatulas, or sticks, which tended to make less noise in the protests. However, in general, the implements chosen reflected an interest in

\footnotetext{
188 Jonathan Sterne, "Quebec's \#casseroles: On Participation, Percussion, and Protest," Sounding Out! June 4, 2012, http://soundstudiesblog.com/2012/06/04/casseroles/.

${ }^{189}$ Sterne, "Quebec's \#casseroles: On Participation, Percussion, and Protest," Sounding Out!

${ }^{190}$ Caroline Echeverria, The Current.
} 
maximizing convenience and volume while minimizing the risk of permanently damaging a household item. ${ }^{191}$

Rhythmically, les manifs tended to settle into a regular, repetitive pattern that extended for long periods of time, with occasional lapses into a less unified cacophony. Rosen describes this experience, noting that it also had an impact on the movement and physicality of the protesters:

There is a strange beauty in collective noise: some people clang in rhythm, some riff off one another, some do their own individual thing. The cacophonous sounds occasionally coalesce into a collective rhythm, prompting your body to move in tune with the crowd, before the pattern dissolves back into chaos. This movement back and forth-between chaos and organization, noise and music-energizes the crowd throughout the evening and into the night. The improvisational music that brings us together has an undeniably anarchic aesthetic. ${ }^{192}$

One rhythm that seems to have recurred fairly frequently during the events was a simple pattern of two quarter notes, two eighth notes, and quarter note. This rhythm was basic enough that it could be played by all participants, while more skilled musicians used it as a base for more complicated patterns. As the crowd generated energy, tempo often increased (or decreased) accordingly. ${ }^{193}$ Rosen observes that the coordinated rhythm was often combined with coordinated movement-for example, it was particularly common to see protesters alternating between striking the pot low, at waist height, and raising it above the head to

\footnotetext{
${ }^{191}$ Echeverria nevertheless describes the pride that Chileans felt over dented or warped pots and pans that had been used to protest Pinochet.

${ }_{192}^{192}$ Rosen, 2012.

${ }^{193}$ This rhythm features prominently in several sections of the following composite of excerpts from a May 27 manif in Villeray: "Casseroles Villeray 27 mai 2012," YouTube video, 5:03, posted by Patrick Lecuyer, May 27, 2012, accessed April 1, 2014, http://www.youtube.com/watch?v=NS0QxIIEjCO\#t=209.
} 
strike it high in the air. ${ }^{194}$ Sometimes the dominant rhythm that emerged was performed in synchronicity with a vocal chant, such as the infamous "la loi spéciale, on s'en câlisse."195

The spontaneous, constantly evolving nature of les casseroles and cacerolazos and their resistance to notation make them akin to improvisatory musical performance. While premeditated, and the performance itself assigned a specific plan or structure in advance, les casseroles were variable in the way they unfolded, with protesters reacting to the changing environment around them as they marched. As is commonly the case with improvisation, openness and inclusivity were emphasized: avant-garde guitarist and improviser Derek Bailey describes improvisation as "open to use by almost anyone-beginners, children, and non-musicians... It can be an activity of enormous complexity and sophistication, or the simplest and most direct expression.." ${ }^{196}$ In this way, les casseroles remained open to any number of participants, performing any manner of instrument-even more conventional musical instruments, particularly trumpets and saxophones, accompanied the pots and pans at times.

Charivaris, cacerolazos, and les manifs casseroles challenge the boundaries of what is considered music_as a result, musicologists often come up with different terms that qualify the musicality of the practices. Musicologists have most frequently studied this tradition in the form of charivaris, and the terms

\footnotetext{
${ }^{194}$ For an example of this, see this video of a manif on May 23 in Villeray: "Super Manif de casseroles dans Villeray," YouTube video, 2:21, Posted by Alex Delcourt, May 23, 2012, accessed April 1, 2014, http://www.youtube.com/watch?v=cUZKqheNT68.

${ }^{195}$ See Chapter 1, page 34. Sterne, Sounding Out!, 2012.

${ }^{196}$ Derek Bailey, Improvisation: It's nature and practice in music (Cambridge, MA: Da Capo Press, Inc., 1992), 83-84.
} 
used tend to emphasize its precarious place straddling the boundaries of music/noise and speech/song; Marcel Dubois describes it as "paramusic," signifying its place auxiliary to, rather than incorporated under, the label of music. In the Dictionnaire de la Musique en France aux XVII et XVIII, charivari is defined as a "concert grotesque." ${ }^{197}$ The medieval Scottish and English version of charivari is known as "rough music," tempering its categorization as music through the addition of the adjective "rough." 198 In general, while scholars describe and analyze the sounds of charivari using musical terms, they frequently qualify its position in music through the use of descriptive labels.

Stéphane Roth and Isabelle Soraru question why charivaris have so rarely been considered a musical art, and come to the conclusion that it is a systematic devaluation of music that deviates from normative tastes and aesthetics. They note that music that initially met with resistance-such as the works of the Second Viennese School—was described in similarly dismissive terms, before ultimately being accepted as part of the musical canon. ${ }^{199}$ Robic points out that the charivari is not so different from other customs studied under the umbrella of ethnomusicological study, and that it is only within the Western art tradition and canon that it would not be considered musical. ${ }^{200}$ Dillon writes that in the Middle Ages, charivaris were not spontaneous outbursts, but deliberate and

\footnotetext{
${ }^{197}$ Benoit Marcelle, Dictionnaire de la Musique en France aux XVII et XVIII, (French and European Publications, 1992)

${ }_{198}$ Dillon, The Sense of Sound, 92.

199 Stéphane Roth and Isabelle Soraru, Dire la musique: À la limite, (Paris, France: L'Harmattan, 2012): 201. Roth and Soraru recount the story of critic René Brangour saying that Arnold Schoenberg's music is "more vulgar and incoherent than a charivari".

${ }^{200}$ Robic, 102.
} 
premeditated events, "produced as part of a defined ritual—as intentional as musical performance."201

Susan Crane agrees about the performative nature of charivaris: in The Performance of Self, it comprises one of several examples she uses of "formalized, ceremonial, and ritual situations that invite self-definition into visible and audible performance." ${ }^{202}$ She does, however, relate it more closely to theatrical rather than musical performance, and rarely uses musicological terms in her analysis of the phenomenon. Marcela Fuentes includes cacerolazos as an example in her study of "performances of dissent," and how they can be theorized as events; she explores many examples of the use of theatricality by activists and artists in mobilizing and disrupting "art/life binaries." ${ }^{203}$ It is easy to see how a movement that transforms everyday objects into instruments of music and protest might create such a disruption. The propensity for casserole protests to transcend or confuse boundaries, such as speech/song and music/noise, has already been noted; they also complicate the distinction between artist and activist.

\section{Conclusion}

In their study on the matter of charivaris, Roth and Soraru come to the conclusion that despite the unusual choices of instrumentation, there is no reason charivaris should be excluded from musicological study; it has the

\footnotetext{
201 Dillon, 92.

${ }^{202}$ Crane, 175.

${ }^{203}$ Marcela Fuentes, "In the Event of Performance: Media, Embodiment, and Politics in the Americas," (PhD Diss, New York University, 2008) iv; Fuentes, 15.
} 
elements of timbre, pitch, and rhythm. ${ }^{204}$ The charivari, like les manifs casseroles and cacerolazos, is often perceived as unmelodious, unharmonious, and lacking beauty and order; these traits seem to account for the difficulty many have in conceiving of it as music. Yet I would contend that the challenge the casseroles present to our conceptions of music and musicality is, in fact, part of its purpose. Throughout all of the examples explored, the playing of pots and pans is a rebellious political and social act, and these transgressions are what gives it meaning and makes it such a potent political and social tool. These social and political transgressions are embodied in musical transgressions-defiance of the musical status quo and the cultural limitations placed on music. Its transgressions are what give the act meaning.

The student protesters frequently cite cacerolazos as the inspiration for their protest movements, ${ }^{205}$ while, despite French-Canadian tradition, it is much rarer to hear someone involved with the movement drawing comparisons with charivaris. This might be in part because charivaris have become a rare occurrence in the $20^{\text {th }}$ century Québec; however, they still evoke an image of political protest and rebellion to modern Québécois. ${ }^{206}$ Loco Locass's song Libérez-nous des libéraux, a particularly popular anthem during the 2011-2012 protests, explicitly mentions charivaris in its text. Written for the 2003 Québec election, it experienced a resurgence in popularity as the student movement took shape. The song calls for a "charivari" against the Liberal government, although

\footnotetext{
${ }^{204}$ Roth and Soraru, 202.

${ }^{205}$ See examples of this in Chapter 3, pages 88-89.

206 Jonathan Sterne and Natalie Zemon Davis, "Quebec's manifs casseroles are a call for order," The Globe and Mail, May 31, 2012, http://www.theglobeandmail.com/globe-debate/quebecsmanifs-casseroles-are-a-call-for-order/article4217621/.
} 
even then the idea is still tied to Latin American casserole based protest: "Trêve de paroles, faites du bruit! / Un charivari pour chavirer ce parti, comme en Argentine, en Bolivie.

Overall, there are so many common themes between les manifs casseroles and the charivari and cacerolazo that it makes sense to see them as historical predecessors to the practice, helping shape its meaning and giving it symbolic value. In each iteration, the demonstrations took place outside of private spaces, "a tactical re-territorialization of public space and political discourse, of social formation and cultural production." ${ }^{208}$ As collective rather than individual enterprises, they emphasized the expression and construction of shared community values and standards—standards that they felt were not being upheld sufficiently by the community authorities (governments and churches) ${ }^{209}$ But despite its communal nature, those involved experienced individual empowerment in each case.

\footnotetext{
207 "Enough words, let's make noise! A charivari to capsize [the Liberals], like in Argentina and Bolivia." "Libérez-nous Des Libéraux, Loco Locass," ParolesMania, http://www.parolesmania.com/paroles_loco_locass_58033/paroles_libereznous_des_liberaux_1123038.html. ${ }^{208}$ Tancons, "Occupy Wall Street: Carnival Against Capital?" ${ }^{209}$ Vance, 816.
} 


\section{Chapter 3}

\section{Analyzing Les Casseroles}

\section{History of Frame Analysis}

Gregory Bateson first described the concept of framing in 1954 in a zoological study; he noted that communications between monkeys are interpreted through implied and inferred metamessages. He labeled these "interpretive frames"-for example, a similar action might be viewed as either hostile or playful, depending on the way it was framed. ${ }^{210}$ Since its initial use, the concept has been applied in a number of social sciences contexts, including sociology, political science, linguistics, media studies, policy studies and social psychology. Erving Goffman pioneered the application of framing as a concept in social movement studies in his Frame Analysis (1974); he viewed it as a dynamic, evolving way of assigning meaning to events or occurrences.

Goffman judged that Bateson's frames are a useful concept that can be applied to the organization of experience. He writes, "My aim is to try to isolate some of the basic frameworks of understanding available in our society for making sense out of events and to analyze special vulnerabilities to which these frames of reference are subject." ${ }^{211}$ Individuals do not generate actions on their own, but as a part of a larger organizational premise-what Goffman calls the "frame of the activity." 212 These frames are cognitive structures adopted

${ }^{210}$ Deborah Tannen, Framing in Discourse (Oxford, UK: Oxford University Press, 1993), 1-3.

211 Erving Goffman, "Frame Analysis", in The Goffman Reader, edited by Charles Lemert and Ann Branaman (Malden, MA: Blackwell Publishers Ltd.,1997), 155.

${ }^{212}$ Goffman, "Frame Analysis," 158. 
unconsciously, and as such can be difficult to identify—however, for him they are an innate part of all social activities and processes.

Frame analysis has become a particularly useful tool in the study of social movements, though it is not the only one. In the wake of the Second World War, scholars of social movement studies tended towards collective behaviour theory, which views social movements as irrational and spontaneous. ${ }^{213}$ In the 1960 s, however, scholars found that their beliefs on the irrationality of collective behaviour did not explain or reflect the highly structured and strategic American civil rights movement. ${ }^{214}$ Resource mobilization theory was an attempt to resolve this inadequacy: social movements are instead approached as deliberate, logical groups that acquire resources and then mobilize in pursuit of a political goal, thus emphasizing the intentionality and rationality of protesters. Resource mobilization was a crucial step in acknowledging the rationality and structure of social movements; however, it failed to offer insight into the collective construction and expression of grievances, or to explain why specific movements evolve at a particular time and place. ${ }^{215}$

Political opportunity structure is another very structural example, emerging in Eisinger's 1973 study “The Conditions of Protest Behaviour in American Cities." Political opportunity theory dictates that the success or failure of a

${ }^{213}$ David S. Meyer, "Tending the Vineyard: Cultivating Political Process Research," in Rethinking Social Movements: Structure, Meaning, Emotion, edited by Jeff Goodwin and James M. Jasper (Oxford, UK: Rowman \& Littlefield Publishers, Inc., 2004), 49.

214 Hank Johnston and John A. Noakes, "Frames of Protest: A Road Map to a Perspective," in Frames of Protest: Social Movements and the Framing Perspective, edited by Hank Johnston and John A Noakes (place: Rowman \& Littlefield Publishers Inc., 2005), 4. This change was facilitated by the fact that many scholars of social movements were also participants in the protests, and were more sympathetic to its causes.

${ }^{215}$ Robert D. Benford, "You Could Be the Hundredth Monkey," The Sociology Quarterly 34, 2 (May 1993): 199. 
movement is based on its leaders' ability to identify and then exploit vulnerabilities in the current political system. According to political opportunity theory proponents, social movements begin "in response to political opportunities and then, through collective action, create new ones." ${ }^{216}$ Therefore, in order to answer the question of why a particular movement is created, one should look at when it began, and what political opportunities opened up to allow the movement to take root. Sociologist and political scientist Sydney Tarrow, one of the first major proponents of political opportunity theory, notes that groups lacking in resources often mobilize successfully, while conversely people with many resources at their disposal and significant grievances do not necessarily begin organizing. Tarrow and other political opportunity theorists believe that resources cannot be mobilized effectively without the occurrence of something that agitates or exposes a particular political struggle, division, or issue.

These are two examples of the structural approach to social movement theory that remains the dominant methodology. Often subsumed under the umbrella of political process theory, they emphasize formal organizations and empirically measurable findings. ${ }^{217}$ They are not mutually exclusive-in fact, resource mobilization makes up a key component of opportunity theory, as the resources are part of the political opportunities that present themselves.

Highly structured, rational approaches to social movements, however, do not reflect the complexity and unpredictability of social movements-even with the examination of resources, political context and opportunity, it is still very

\footnotetext{
${ }^{216}$ Sydney Tarrow, Power in Movement (Cambridge, UK: Cambridge University Press, 1998): 17. 217 Jeff Goodwin and James Jasper, "Introduction," in Rethinking Social Movements: Structure, Meaning, and Emotion (Oxford, UK: Rowman \& Littlefield Publishers Inc., 2004), vii.
} 
difficult to predict the initiation of a movement, or the course of that movement once it has started. ${ }^{218}$ Goodwin and Jasper believe that adherence to such structures is born out of "an anxious desire to systematize the unsystematic, to predict the unpredictable, to tame agency by reducing it to structure..219 In response to these problems, some sociologists have turned to a cultural or constructionist approach emphasizing the construction of narratives and identities, the assignment of meaning and the role that emotions, agency, and interaction play in social movements. ${ }^{220}$ Frame analysis is one method used by sociologists to acknowledge the importance of subjectivity, human agency and interpretation for movement mobilization.

According to frame analysis, movements are not the inevitable outcome of a set of circumstances and structures, but rather the efforts of movement actors, "signifying agents actively engaged in the production and maintenance of meaning for constituents, antagonists, and bystanders or observers." ${ }^{221}$ While political opportunity and resource mobilization theory are still significant to sociological understanding and study of social movements, the last two decades have seen frame analysis take a similarly crucial place in social movement theory. ${ }^{222}$ It is nevertheless worth noting that structural and cultural constructionist approaches do not necessarily need to stand in direct opposition to each other-as Doug McAdam notes in "Revisiting the U.S. Civil Rights

\footnotetext{
${ }^{218}$ Noakes and Johnston, Frames of Protest, 1.

219 Jeff Goodwin and James M. Jasper, Contention in Context: Political Opportunities and the Emergence of Protest (Stanford, CA: Stanford University Press, 2012), 7.

${ }^{220}$ Goodwin and Jasper, "Introduction," vii.

${ }^{221}$ Robert D. Benford and David A. Snow, "Framing Processes and Social Movements: An Overview and Assessment," Annual Review of Sociology 26 (2000): 613.

${ }^{222}$ Benford and Snow, "Framing Processes and Social Movements," 612.
} 
movement," when the "cognitive/affective byproducts of these framing processes are combined with opportunities and organization, chances are great that collective action will develop."223 Given the complexities of social movement studies, a combination of approaches often leads to a more thorough and nuanced understanding of a movement or event. ${ }^{224}$

\section{Collective Action Frames}

One of concepts developed out of the relationship of social movements and frame analysis is that of collective action frames, or frames that act as "emergent action-oriented sets of beliefs and meaning that inspire and legitimate social movement activities and campaigns." ${ }^{225}$ These frames guide interpretation and perception of occurrences, and therefore direct actions and belief systemsthus, they are invaluable in determining what is going on in a situation to encourage or enable protest. ${ }^{226}$ The identification of collective action frames is primarily the work of sociologist David A. Snow, who has written extensively on social movement tactics and participation. Snow and collaborator Robert Benford see collective action frames as the results, or products, of the framing process by which actors (including but not limited to movement leaders, organizations and institutions, bystanders, media and governments) engage with and participate in

\footnotetext{
${ }^{223}$ Doug McAdam, "Revisiting the U. S. Civil Rights Movement: Toward a More Synthetic Understanding of the Origins of Contention," in Rethinking Social Movements: Structure, Meaning, and Emotion (Oxford: Rowman \& Littlefield Publishers Inc., 2004), 204.

${ }^{224}$ Frame analysis has been subject to some of the same criticisms as resource mobilization theory and political opportunity theory; namely that it contains a structural bias. Jasper and Goodwin feel that they still do not emphasize the dynamic and diverse emotional and psychological dimensions of reactions to social movements. I will attempt to alleviate this criticism by including Jasper's work on emotions in protest movements in conjunction with Benford and Snow's work on collective action frames.

${ }^{225}$ Benford, "Hundredth Monkey," 199.

${ }^{226}$ Noakes and Johnston, Frames of Protest, 2.
} 
meaning construction. ${ }^{227}$ Goffman describes frames as selectively simplifying objects, experiences and environments so that they can be more readily understood. In the case of collective action frames, this is done by emphasizing or accenting the importance, injustice, or immorality of a social condition that is seen as a grievance. ${ }^{228}$

Snow and Benford assign the functions of attribution and articulation to collective action frames. Both allow framing to identify problems (diagnostic frames), present solutions (prognostic frames), or to inspire people to action (mobilization frames). Diagnostic and prognostic framing both involve the attribution of shared, negotiated meaning and understanding for an issue or situation. Diagnostic framing attributes assign fault to an agent-whether a person, a process, or a structure-thereby giving the movement a culpable party to focus on. Similarly, prognostic frames attribute responsibility for a solution to a particular agent-ideally, such frames provide a sense of how corrective action should unfold in order to achieve the movement's goals. ${ }^{229}$

The identification of problems and solutions must be accompanied by the articulation of a compelling argument for an individual to join and take action within the protesting group. Motivational framing encourages active participation rather than passive support; it includes a "call to arms" for engaging in action, as well as a rationale and justification for the movement's actions. ${ }^{230}$ The vast majority of sympathizers with a protest movement never actually become active

\footnotetext{
${ }^{227}$ Snow and Benford, Frontiers, 136

${ }^{228}$ Snow and Benford, Frontiers, 137.

${ }^{229}$ Snow and Benford, Frontiers, 137.

${ }^{230}$ Benford, "Hundredth Monkey," 200.
} 
demonstrators; as such, a persuasive reason giving someone a personal investment in the issue is necessary to incentivize joining the movement. ${ }^{231} \mathrm{~A}$ mobilization frame brings these sympathizers into a movement. It also needs to reduce the barriers to participation, including the cost of time, effort, and potentially money, as well as the risk of violence. ${ }^{232}$ It is my belief that les casseroles acted like one of these mobilization frames.

Benford's work on mobilization frames in the US nuclear disarmament movement argues that the construction of a vocabulary is one way by which they work. ${ }^{233}$ In order to overcome the apathy of the general public, Benford finds that Social Movement Organizations (SMOs) must frame the problem in terms of its severity and urgency, and the action being taken in terms of its efficacy and propriety. The Montréal protesters did this, namely through language that emphasized the direness of their situation, like in this excerpt from a blog post by Ethan Cox in response the mass arrests on May 23:

...I woke this morning genuinely afraid. For the first time in my life I am afraid of what can happen to me, and to my friends and neighbors and strangers, if we exercise inalienable rights that we cannot, must not, forfeit. This is not hyperbole, it is fact, and the fact is that the world looks a great deal darker today. ${ }^{234}$

The protesters' rhetoric frequently invokes fear and anxiety, with the underlying message that those who opposed protesters are participants in a repressive, dictatorial status quo:

\footnotetext{
${ }^{231}$ Benford and Snow, "Framing Processes and Social Movements," 615.

${ }^{232}$ Stefaan Walgrave and Jan Manssens, "Mobilizing the White March: Media Frames as Alternatives to Social Movement Organizations," in Frames of Protest, 115.

${ }^{233}$ Benford, "Hundredth Monkey," 200.

234 Ethan Cox, "'There is no Right to Protest' : Montreal Police Deny Charter Rights," Rabble.ca, March 23, 2013, http://rabble.ca/blogs/bloggers/ethan-cox/2013/03/there-no-right-protestmontreal-police-deny-charter-rights.
} 
Que des jeunes, et des moins jeunes, reçoivent des contraventions de 614 dollars pour avoir participé à des assemblées publiques fait peur. Que des mouvements de protestation soient brimés dès lors qu'ils se forment fait peur. Que des policiers détiennent massivement des citoyens pour rien fait peur. Qu'on confonde interpellation policière et arrestation arbitraire pour avoir exercé un droit constitutionnel fait peur.

Ce qui fait peur, à Montréal, actuellement, c'est la police avec ses déclarations totalitaires. Ce qui fait peur c'est l'État et son mode de gouvernance. ${ }^{235}$

After the introduction of Bill 78 and the beginning of les manifs casseroles, the language surrounding the movement became increasingly dramatic and urgent, with an alarmist undertone. In general, the protesters established a vocabulary that was steeped in fear: fear of dictatorship, loss of freedoms and loss of constitutional rights.

The manifs casseroles were able to extend this vocabulary to new audiences and mobilize new protest sympathizers. As a mobilization frame, les casseroles were also able to reduce barriers to activism by using common household objects, thereby eliminating possible language barriers in a bilingual city. In addition, the protests became more accessible-for those with reduced mobility, it was possible to lend support from the relative safety and comfort of a home or apartment balcony. It also requires a little planning or forethought, since anyone within earshot knows when and how to join in. Les casseroles have also been credited with expanding the demographics of the protesters to include not

\footnotetext{
${ }^{235}$ Véronique Robert, "Avoir peur de la police, pas des manifs," Voir.ca, March 23, 2013, http://voir.ca/veronique-robert/2013/03/23/avoir-peur-de-la-police-pas-des-manifs/. "When youth receive $\$ 614$ tickets for participating in a public assembly, be afraid. When protest movements are bullied when they are formed be afraid. When the police detain masses of citizens for no reason, be afraid. When police arrest arbitrarily for exercising a constitutional right, be afraid. What we should be afraid of in Montreal, in actuality, is the police with their totalitarian declarations. What we should fear is the state and its method of governance."
} 
just youth and students, but children, seniors, and middle-aged men and women. The Facebook group "Nos casseroles contre la loi spéciale" advertises the tactic's intergenerational appeal by sharing photos of participants of different ages, including one photo of four generations of women from a family participating in les casseroles:

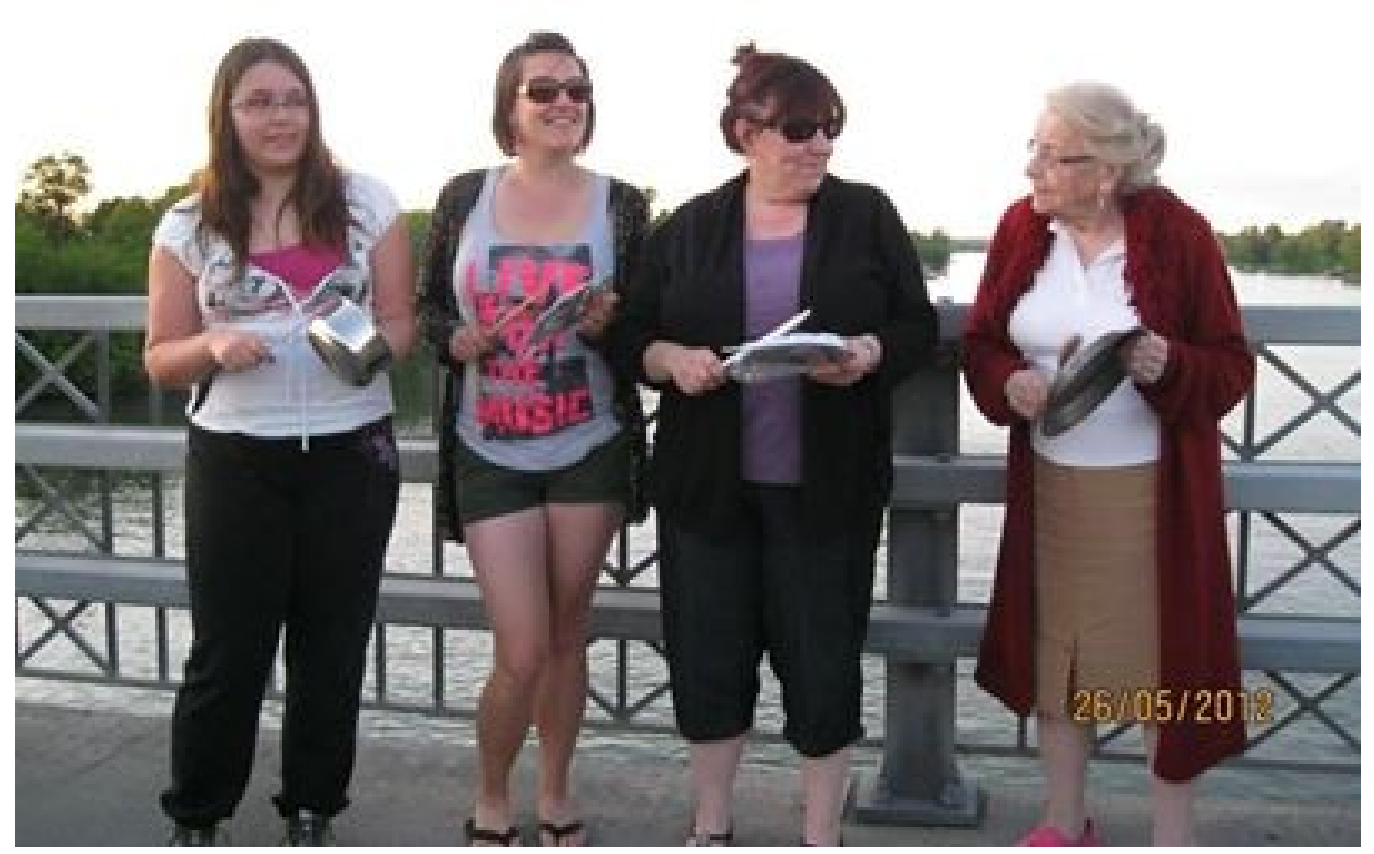

Photo originally shared on Facebook by Carole Fortin, who writes "Je vous présente 4 générations de femmes qui protestent avec leur casserole pour défendre notre liberté d'expression. ${ }^{236}$

\section{Frame Resonance}

A number of interrelated factors influence the success of such frames, including their congruency, consistency and credibility. Snow and Benford note that frames can help movements focus their tactics by using collective action

\footnotetext{
236 "I present to you 4 generations of women who protest with their casseroles to defend our freedom of expression." Note that the fourth generation, a child, does not appear in the photograph.
} 
frames that are consistent with the movement's prognostic and diagnostic resolutions. One example they use is the American civil rights movement, in which protesters deployed methods like sit-ins and freedom rides to demonstrate against the institutionalization of racial prejudice and segregation through Jim Crow laws. ${ }^{237}$ These tactics were non-violent and accessible and due to their consistency with both the movement's prognostic and diagnostic assertions, the frames were successful in "dramatizing for the entire nation the substance of the claims articulated by the civil rights movement's master frame."238 By contrast, tactics like riots and sabotage were incongruent with the movement's rhetoric of nonviolence and inclusivity and damaging to its reputation. Benford describes one example of such an inconsistency in the nuclear disarmament movement, which framed its protestors as having deeply held values of peace and respect for life. In the summer of 1985, however, a disarmament activist detached a portion of the railway track servicing a nuclear weapons facility in Texas, an action with potentially life-threatening consequences. As a result of this incongruence in the disarmament movement's collective action frames, the credibility of the entire movement was damaged. ${ }^{239}$

\footnotetext{
${ }^{237} \mathrm{Jim}$ Crow laws existed in many states within the United States from 1877 until the 1960s, enforcing racial segregation. Public facilities, such as churches, hospitals, schools, libraries, modes of transportation, and restrooms, were either divided according to race or exclusively served either white or black people, with those facilities offered to blacks inferior in quality. While blacks ostensibly had the same constitutional legal protections as whites, Jim Crow laws were a way of guarding white supremacy under the guise of "equal but separate" treatment. David Pilgrim, "What Was Jim Crow?" Ferris State University, Sept. 2012, http://www.ferris.edu/jimcrow/what.htm.

${ }^{238}$ Snow and Benford, Frontiers, 146. A master frame is a larger collective action frame that ties together the movement.

${ }^{239}$ Benford, "Hundredth Monkey," 147 . It is notable that in this case, as in many cases, the actions of a single individual are equated with those of an entire group, even when the individual acted without any support from the group/movement he or she claims to represent.
} 
This combination of credibility, congruency, and consistency is the basis of what Snow and Benford call a frame's "resonance." Resonance is the result of "the credibility of the proffered frame and its relative salience," including the congruency between the stated objectives and values of the social movement and its actions. The perceived reliability and integrity of the leaders as well as their ability to verify the problems being presented with tangible evidence from their own experiences also contribute to a frame's resonance. While it was perhaps difficult for those outside the movement to verify the claims about the negative impact of raised tuition by students, the rhetoric surrounding les casseroles could be more easily verified by observing police behaviour at protests and public statements by government officials. The overall effectiveness of a mobilization frame is impacted by its resonance: Snow and Benford observe that "the greater and more transparent the apparent contradictions in either realm, the less resonant the proffered framing(s) and the more problematic the mobilization." 240

Some of the Québec student unions' initial actions lacked consistency of message, caused by an inherent contradiction between their goals and their chosen strategies for achieving these goals. The reactions of the broader media and public to the Montréal student protests reveal that the frames mobilized prior to the passage of Bill 78 and the enactment of les casseroles tended to have less resonance, something which I believe is the result of incongruence between their message and methods in the protest's early days. As discussed in the opening

$\overline{{ }^{240} \text { Benford and Snow, 2000, } 619 .}$ 
chapter, ${ }^{241}$ the students' primary concern was free access to education and one of their chosen ways of demonstrating in favour of this free access was in fact to block access to educational institutions. In addition to physically blocking entrances and exits, striking students would often disrupt classes by turning lights on and off or creating noise. ${ }^{242}$ Québec has a history of legitimating student strikes, and the students themselves could articulately explain their views that as students, they were not passive consumers of education but actively contributing to Québec society. Nonetheless, by preventing non-protesting, paying students from access to education, their method of protest was inconsistent with their overall goals, rendering the students' collective action frames as "vulnerable to dismissal." ${ }^{243}$

However, Bill 78 gave the students the opportunity to reframe their movement as being about the values of the right to organize and demonstrate, the right to public space, and freedom of expression. Reframing the movement in this manner placed it more firmly within an "injustice frame," one of the most studied collective action frames. Injustice frames represent attempts to position a social movement as a response to unjust victimization; its goal is to foster anger and outrage among the broader public over a social condition, often by personalizing the perceived injustice. ${ }^{244}$

\footnotetext{
${ }^{241}$ See Chapter 1, page 20.

242 Jacob T. Levy, "The high cost of low tuition in Quebec," Academic Matters, 13.

${ }^{243}$ Snow and Benford, Frontiers, 147.

244 Benford and Snow, 2000, 615; Ronald R. Aminzade and Doug McAdam, "Emotions and Contentious Politics," in Silence and Voice in Contentious Politics, edited by Ronald R. Aminzade et al, (Cambridge, UK: Cambridge University Press, 2001), 32.
} 
Sociologist and political scientist Donatella Della Porta observes that in the face of pressure or outright aggression from an external force, social movements often become more intense and gain popularity. ${ }^{245}$ When authority figures use violent or repressive tactics against protesters, it is not usually regarded as an isolated incidence but rather as a symptom of a larger, systemic problem. As a result, their grievances are seen as more credible, urgent and severe by the general public, who are then more likely to join the movement or, in the case of news media, portray them sympathetically. ${ }^{246}$ In the example of the Montréal protests, the government attempted to force an end to the protests with Bill 78, and the police were seen as aggressive in their use of pepper spray and kettling as containment tactics within the first week of the law's announcement. These practices generated a significant amount of negative publicity, and warranted the protesters to make more credible use of the injustice frame. In an effort to distance themselves from the adverse reaction to the mass arrests and kettling that took place, and to avoid reinforcing the protesters' injustice frames, officers largely ceased crowd control and containment tactics as les casseroles gained popularity. Because of this, les casseroles ultimately had a positive impact on the interactions of the protesters with the police. Concordia University postdoctoral fellow and protester Joseph Rosen credits les casseroles with having "transformed pepper-spraying police into local parade escorts." ${ }^{247}$

\footnotetext{
${ }^{245}$ Donatella Della Porta, "Eventful Protest, Global Conflicts: Social Mechanisms in the Reproduction of Protest," in Contention in Context: Political Opportunities and the Emergence of Protest, edited by Jeff Goodwin and James M. Jasper (Stanford, CA: Stanford University Press, 2012), 270.

${ }^{246}$ Aminzade and McAdam, "Emotions and Contentious Politics," 44.

${ }^{247}$ Rosen, 2012.
} 
By exploiting the power inherent in injustice frames to create a sympathetic narrative and strengthen collective identification with the social movement, the Québec students were able to inspire greater participation than they previously had. Les casseroles expressed the right of assembly and freedom of association clearly, without mixed signals: while the tuition increasenot such a popular cause-had inspired the initial movement, the protests were reframed in response to Bill 78 as being about political expression and community solidarity. One Facebook event for a march in July of 2012 exhorts participants to "protect free expression, and stand up to oppression! Let's show the world that when politicians try to silence the people, the people come out singing!"248

The protester rhetoric surrounding les casseroles was one way that injustice frames were implemented; however, the history and roots of les casseroles also served to emphasize the injustice of Bill 78. Students often drew connections between the situation in Québec and the roots of les casseroles in the South American tradition of cacerolazos:

Dans des circonstances où la dictature chilienne a limité les attroupements illégaux à tout regroupement de plus de 4 personnes, les citoyens chiliens ont utilisé ce moyen pour exprimer leur colère. Inspironsnous d'eux et QUE LES CASSEROLES DU QUÉBEC S'EXPRIMENT!!! ${ }^{249}$

It is interesting to note that the only language other than French and English into which the Manifesto is translated is Spanish, perhaps acknowledging that the

\footnotetext{
248 "On appele tous les musicien(ne)s: L'orchestrole du Mile-End," https://www.facebook.com/events/408425942526577/.

249 "In circumstances where the Chilean dictatorship made illegal gatherings of any group of more than four people, the Chilean citizens used this medium to express their anger. Let us draw inspiration from them and what the casseroles of Québec express!!!" "Nos Casseroles Contre La Loi Spéciale," Facebook, May 2012, https://www.facebook.com/NosCasserolesContreLaLoiSpeciale/info.
} 
Chilean student protests and indignados were influential on the Québec student protests. But even when explicit connections are not drawn to the Chilean dictatorship, the language used to describe Bill 78 often suggested it was tyrannical and dictatorial. One poem by Montréal citizen Félix Morin calls it "l'affront d'un tyran devant un peuple libre," and continues by saying he will "crache sur les lois de vos scribes / Mes poignets sont libres de vos chaînes." 250 Similarly, L'Université du Québec à Montréal student Chantal Bertrand writes that Bill 78 "fait violence à mes droits fondamentaux, à ma démocratie!" 251 and CÉGEP student Béatrice Venne explains her participation in the protests: "Le mépris. La repression. L'oppression. Ce sont des choses que je retiens de notre combat." 252

In an interview with Le Devoir, the teacher who originated les casseroles, François-Olivier Chené, acknowledged the severity of the rhetoric surrounding Bill 78 and the comparisons to Pinochet's Chile: "Évidemment, nous ne vivons pas dans une dictature. Par contre, cette loi-là est un pas dans la mauvaise direction." ${ }^{253}$ Student blogger "Julinthesky" writes that, "Comme nous ne sommes pas [encore] sous une dictature aussi drastique que celle du Chili"[sic]—implying that while the situation is not as dire as it was in Chile, the restrictions on

\footnotetext{
250 "The affront of a tyrant to a free people." Félix Morin, Le Carré Rouge, 34.

251 "[Bill 78] does violence to my fundamental rights, my democracy!" Chantal Bertrand Le Carré Rouge, 20.

252 "Contempt. Repression. Oppression. These are the things I retain from our fight." Béatrice Venne, Le Carré Rouge, 27.

253 "Evidently we do not live in a dictatorship. But then, this law [Bill 78] is heading in a bad direction." Marco Bélair-Cirino, "Grand tintamarre contre la loi 78-Les casseroles s'en mêlent," Le Devoir, May 24, 2012, http://www.ledevoir.com/societe/actualites-en-societe/350783/lescasseroles-s-en-melent.
} 
freedom of assembly are comparable. ${ }^{254}$ As explored in chapter 2, (see pages 37-39) the cacerolazo actually originated as a protest against the democratically elected Salvador Allende—-however, the Québec protesters consistently only connect the tradition Pinochet's regime. This is probably attributable to two factors. On the one hand, the protesters themselves possessed left-wing tendencies, adopting the casserole as a symbol of socialism, and for whom its anti-socialist origins would be problematic. On the other, the indisputable injustice of the Pinochet regime better served their mobilization frame.

Parallels have also been drawn to the Prime Minister Pierre Elliott Trudeau's controversial imposition of martial law during the October Crisis of 1970 , which drew harsh criticism. ${ }^{255}$ In the wake of a series of bombings and two kidnappings by the Québec nationalist group Front de Liberation Québec, Trudeau invoked the War Measures Act (WMA). Intended for use in maintaining security during times of war or insurrection, the WMA suspended civil liberties across Canada in the name of combating terrorism. ${ }^{256}$ Overall, protesters have not hesitated to associate the implementation of Bill 78 with political situations acknowledged as more severe and repressive than their own as a way of underscoring the urgency and unfairness of their situation.

\section{Public Space}

\footnotetext{
254 julinthesky, "Concert de Casseroles Contre la Loi Spéciale," May 23, 2012, http://julinthesky.bangbangblog.com/2012/05/23/concert-de-casseroles-contre-la-loi-speciale/. 255 "The October Crisis," http://www.cbc.ca/history/EPISCONTENTSE1EP16CH1PA4LE.html. ${ }^{256}$ The WMA would be replaced by the more refined Emergencies Act in 1988, largely due to its controversial implementation during the October Crisis. The Emergencies Act places restrictions on the government's ability to suspend civil liberties.
} 
Injustice frames were implemented from the very beginning of the student movement, as the tuition hike was framed as a threat to equal access to education. The CLASSE Manifesto positions free education as a moral imperative, and states "by throwing our educational institutions into the marketplace, our most basic rights are being taken from us." ${ }^{257}$ Their materials highlighted incidences of police brutality, and positioned the students as fighting against the dangers of neoliberalism and the political and economic elite, using much of the same rhetoric as the OWS movement. ${ }^{258}$

However, it was when the injustice frames were recast as concerning communal organization and public space that they were most successful in mobilizing protestors. Part of this is undoubtedly due to the fact that les casseroles protests acted like a mobilization frame congruent with these values. Rosen believes that les casseroles provoked such a strong reaction because they reached out to a value deeply held by Montréal's inhabitants: the communal, spontaneous use of public space.

We are a city of festivals, terraces and parks; in the Plateau, we picnic with wine and flowers; on the mountain we bring barbeques and tablecloths. In the spirit of the city, les manifs casseroles transcend the politics of the demand: neither angry nor confrontational, they manifest Montréalers' claims to public space. Vibrations in the air, feet on the street: a literal manifestation of being-together and sharing pleasure in public space. ${ }^{259}$

With Montréalers so integrally attached to the idea of shared and public space, the use of les casseroles combined with the rhetoric of the protestors

\footnotetext{
257 "Manifesto," CLASSE.

258 "March $22^{\text {nd. }}: 200000$ took to the streets!", CLASSE, http://www.stopthehike.ca/wpcontent/uploads/2012/03/ExpressEN.pdf.

${ }^{259}$ Rosen, 2012.
} 
framed Bill 78 as a violation of freedom of assembly. This is a frame that resonated deeply with Montréalers, and attracted new participants to the protests. Journalist Jacob Serebin observes that while the original protests were almost entirely young francophones, "the casserole protesters are different. It's no longer just French students and ardent leftists. It's a cross-section of the community, with people of all ages and ethnic backgrounds. Their constant clanging, along with the presence of older people and small children, gives these protests a festive air." ${ }^{260}$ During les manifs casseroles, there was "little mention of the tuition hikes"-Bill 78 became the main focus instead. ${ }^{261}$

This emphasis on public space echoes throughout the Occupy Wall Street and 15M (los/las indignados/indignadas) movements. Matt Stoller, former policy advisor to Rep. Alan Grayson, describes the use of the public space by OWS as follows: "a space made sacred by a community... It has become many things. Public square. Carnival. Place to get news. Daycare center. Health care center. Concert venue. Library. Performance space. School." ${ }^{262}$ This is a familiar sentiment to citizens of Montréal, a city where a constant stream of performances, art exhibitions, workshops, activities, fairs and festivals means that the city space is a lively, constantly changing presence in their lives. ${ }^{263}$ With the help of tactics like les casseroles, the student strike "strategically and astutely

\footnotetext{
${ }^{260}$ Jacob Serebin, "Quebec's pots and pans protesters: Forget Tuition. It's all about Bill 78 now," Maclean's, http://oncampus.macleans.ca/education/2012/05/29/quebecs-pots-and-pansprotesters/. This "festive air" is also carnivalesque in nature, as discussed in chapter 2 of this thesis.

${ }^{261}$ Ibid.

${ }^{262}$ Matt Stoller, "\#OccupyWallStreet Is a Church of Dissent, Not a Protest," Naked Capitalism, September 29, 2011, http://www.nakedcapitalism.com/2011/10/matt-stoller-the-anti-politics-ofoccupywallstreet.html.

263 "Montrêal by Theme," Tourisme Montrêal, http://www.tourisme-montreal.org/Discovermontreal/Montreal-by-theme
} 
was about making, inventing and producing new spaces, again both figuratively and literally." ${ }^{264}$ This tactic allowed those who were interested in celebrating and affirming the value of public assembly and space in Montréal to join in the protests, thereby lessening the emphasis on the more divisive topic of tuition hikes.

Exerting control over the soundscape of the city was an important way for the citizens of Montréal to lay claim to their cherished space. Les casseroles bear similarities to other sonic protest tactics, including the human microphone during Occupy Wall Street. Electronically amplified sound is not permitted in public spaces in New York, so the Occupy protestors had to develop their own method of disseminating information. The method they developed the "human microphone" involves repeating the words of a speaker in unison in order amplify the sound and convey messages to everyone present. While the functions of les casseroles and the human microphone are quite different, there are noteworthy similarities between the two methods, particularly in the way they encourage wide participation. Stoller describes the impact of the human microphone on him as a protester:

I felt completely included as part of a community forum even though I had not been a speaker. But what I realized is that the act of listening, embedded in the active reflecting of what the speaker was saying, created a far richer conversational space. ... There is nothing so euphoric in a community sense as truly feeling heard. That's what the general assembly was about, not a democracy in the sense of voting, but a democracy in the sense of truly respecting the humanity of everyone in the forum. It took work. It took patience. But it created a communal sense of power. ${ }^{265}$

\footnotetext{
${ }^{264}$ Cindy Milstein, "Manifest Your Dreams, Montreal, Prelude to Night 73 (in C minor)," Outside the Circle, July 3, 2012, http://cbmilstein.wordpress.com/2012/07/03/manifest-your-dreamsmontreal-prelude-to-night-73-in-c-minor/.

${ }^{265}$ Stoller, 2011.
} 
In the case of the human microphone, Stoller finds that the act of repeating the speaker's words forced reflection and active listening among the protesters and fostered dialogue. In a similar way, les casseroles were able to disassemble some of the traditional hierarchies of performance. While leaders can emerge in each type of performance-designated speakers the human microphone, and those who initiate particular chants and rhythms during les casseroles-everyone participates in the creation of sound, democratizing the soundscape of the protests.

Looking at music created in such a creative, collective manner supports the idea that it is a process rather than a product. Thomas Turino's Music as Social Life: The Politics of Participation explores the idea of process- rather than product-driven musics at length, dividing events into "participatory performance" and "presentational performance." ${ }^{266}$ Presentational performance is that in which a division exists between the creators of art and music and the audience for which it is performed, while participatory performance maintains no such distinctions. Instead, there are "only participants and potential participants performing different roles, and the primary goal is to involve the maximum number of people in some performance role." ${ }^{267}$ Les manifs casseroles fall into the latter category, with the success of the protest judged on its ability to mobilize further participation. Participatory performance is also an extended social interaction and opportunity for social bonding, the sort of bonding frequently

\footnotetext{
266 Turino, 26.

267 Turino, 26.
} 
described by protesters during les casseroles. ${ }^{268}$ As an open-ended and ongoing form of performance, it could be adapted for any length of protest with any number of attendees.

By fostering participatory performance, the Québec student protesters framed their cause as one of inclusiveness and accessibility. The music reflected this with simple, repetitive rhythms, arranged to be easily understandable and imitable by listeners who might choose to join in. There are risks associated with this approach —it could lead to the sonic realm of the manifs being devalued as amateur or unprofessional, and the repetitiveness of the music, while energizing to participants, could become irritating or "underwhelming" to bystanders. Such simplicity, however, is necessary to encourage participation regardless of musical ability-Turino suggests that with participatory music, social skills like cooperativeness and charisma are valued over other talents. ${ }^{269}$ Without conductors, facilitators, or instructors, participatory performances emphasize an approach to music-making that is intuitive, simple, and highly egalitarian.

In addition to creating an open and inclusive format for protest, participatory performance can also create a communal sense of power, as Stoller and Deaville have observed in their discussions of the role of the human microphone during Occupy Wall Street protests (see page 16). ${ }^{270}$ Participatory performance is a way of empowering people through the act of collective music-making. Through (musical) sound, les casseroles allowed the protesters to lay claim to the public

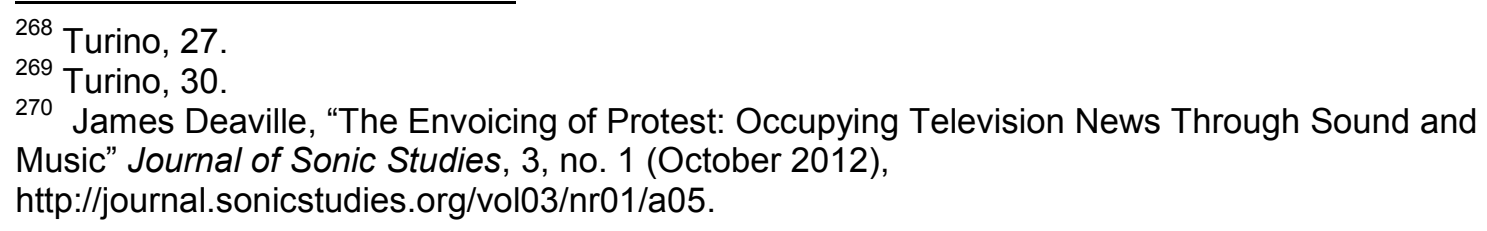


spaces of Montréal, spaces that Montréalers perceived as under attack by Charest's government. By changing the soundscapes of the city, they were able to reframe the protest: as reporter Les Perraux wrote, the "din of wooden-spoonon-wok overtook the soundscape Montréalers had grown to fear: rocks thrown against glass, fusillades of plastic bullets and police helicopters flying overhead." 271

Writing on acoustic ecology, ethnomusicologist Helmi Järviluoma-Mäkelä remarks on the idea of the creation of sound as an expression of agency: "If we trust that even the smallest acts can have an effect on the state of environmentin this case, the acoustic environment-it is possible for us to feel empowered." ${ }^{272}$ The student protesters and their allies manifest this empowerment as they undertook influencing the city's soundscapes through their nightly protests. In addition, they began creating space for themselves in the city's many cultural and musical festivities, such as the "artistic intervention" of the HOWL Arts Collective in the Festival International de Jazz de Montréal. Called the Rêve Général Illimité, it was not an intervention in the sense of stopping to interrupting the Festival International de Jazz itself, but rather intervening in established narratives of Festival's dominance. Its goals were twofold. First, organizers wished to draw attention to the creativity of the student movement through musical, theatrical and visual art installations at Métro St.Laurent, where many festival-goers passed through. They also wanted to protest

\footnotetext{
${ }^{271}$ Perraux, 2012.

272 Helmi Järviluoma-Mäkelä, "Re-sounding Pleasure in Soundscape Studies," Wi Mobilities 7. No. 1 (March 2013), http://wi.mobilities.ca/re-sounding-pleasure-in-soundscapestudies/\#sthash.XhvFNacF.dpuf.
} 
the Jazz Festival itself: "As community artists based in this city, we feel the corporate sponsorship now driving the festival ultimately undermines the political, social, economic and physical space that allows indpendent [sic] culture to thrive in Montréal." ${ }^{273}$ Masked musicians played jazz-inspired tunes, and casseroles joined in the musical festivities at points throughout the intervention. ${ }^{274}$ Empowered and enabled by the momentum created by the mobilization frames of les manifs casseroles, they used it to create their own artistic and musical intervention, challenging the more dominant soundscape of the jazz festival. ${ }^{275}$

Another tactic related to the casseroles was one nicknamed by Cindy Milstein "orchestroles," a combination of musical instruments and pots and pans. Similar to Chené, Milstein notes the difficulty of sustaining a social movement, and the exhaustion that equally wears down protesters, bystanders and police. Milstein, as a journalist sympathetic to the protesters and their cause, sees the musical and artistic tendencies of the movement as indicative of the creativity with which the students wrote "their own script, strategically and astutely.... That script has also been a figurative and sometimes literal multimedia work of art and labor of love, with its component parts ranging, figuratively and maybe literally too, from jazz improvisation-composition to street art to dérive to high theatrics

\footnotetext{
273 "Rêve Général Illimité au Festival du Jazz de Montréal " Howl Arts Collective, July 2, 2012, http://howlarts.net/post/26376871104/reve-general-illimite-au-festival-du-jazz-de-montreal.

${ }^{274}$ Heri, "Rêve Général Illimité au Festival de Jazz de Montréal, par @heri," Vimeo Video, 4:10, http://vimeo.com/45327653.

${ }^{275}$ This argument is similar to an Occupy Wall Street protest led by Philip Glass during/after a performance of his opera Satyagraha at the Lincoln Center. Glass, using the human microphone, noted that since the opera is on the subject of Gandhi's experiences in South Africa and the way they inspired his passive resistance movement, there exists "a certain disparity between its lofty moral message and the machinery of corporate arts funding." Alex Ross, "The Satyagraha Protest (updated)," The Rest is Noise (blog), December 2, 2011, http://www.therestisnoise.com/2011/12/the-satyagraha-protest.html.
} 
and grand oratory." ${ }^{276}$ While Milstein's investment in the movement might make her prone to overstating its artistic substance, it is true that artistic innovation and the use of flexible, fluid protest tactics played an important role in capturing media attention and sustaining engagement in the movement. Essentially, what Milstein is describing could be the process of framing and reframing the conflict: the protesters wished to maintain the momentum of les manifs casseroles and the engagement, increased attention and sympathy it engendered.

When Chené first imagined les casseroles, ${ }^{277}$ it was as a means of dismantling the increasing tension between police and protesters. He believed that the student movement needed a new, less confrontational way of demonstrating that would change their/its relationship with the police and bystanders. In reaction to Bill 78 , the original Facebook event he created in May 2012 suggested that protesters create noise with pots and pans from primarily private space, such as balconies, homes, and sidewalks. The initial plan was to demonstrate for only 15 minutes, between 8:00 and 8:15 each night, and then disband, thereby not blocking traffic or making invasive use of public space. Thus he hoped not to provoke a violent response from authorities: "The students were exhausted. The police were, too. Not all students are communists and anarchists, not all police abuse their power. The tension was high, and this gave everybody a way out."278

One of the most important side effects of the casserole performances, however, extended beyond reframing the conflict and choosing actions that were

\footnotetext{
${ }^{276}$ Milstein, "Manifest Your Dreams," 2012.

277 See Chapter 1, pages 32-33.

${ }^{278}$ Perraux, 2012.
} 
more congruent and consistent with the students' message: it also involved the cooperative, rhythmic nature of the performance. Kevin Audet-Vallée, a graduate student at the Université de Montréal and someone who was previously unsympathetic to the student movement, expressed it this way: "It was suddenly a lot harder to paint the students as violent radicals. Students aren't even the dominant force any more... It's completely peaceful, and it's filled with average Joes." ${ }^{279}$ When the students were being painted as irresponsible and anarchic, les casseroles could fight this image, largely due to the steady, orderly, and rhythmic nature of the music. Even if one did not agree with the initial protests, it was possible to support les manifs casseroles. And thus, although Audet-Vallée had been frustrated with the movement's early protest tactics, particularly those that devolved into violence such as riots and vandalism (see page 27), he became a participant in les casseroles. Audet-Vallée related the following to a reporter in May of 2012: "Things have happened so fast, we have a tendency to forget two weeks ago there was a riot with fires in the street and people were talking about calling in the army... The casseroles changed the game." ${ }^{280}$ AudetVallée's change of opinion was echoed by many Montréalers, something that McGill political science professor Phillip Oxhorn feels was the result of the clearly nonviolent nature les manifs casseroles.

\section{Theorizing the Success of Les Manifs Casseroles}

Collective movement and song is more than just a way of articulating personal principles and freedoms; it is a powerful force for social cohesion and

\footnotetext{
${ }^{279}$ Perraux, 2012.

${ }^{280}$ Perraux, 2012.
} 
group formation. Moving and creating sound in unison blurs the boundaries between the individual and the group, so that a collective identity is formed by such framing ideologies. In this way musical rituals like les manifs casseroles become "symbolic embodiments, at salient times and places, of the beliefs and feelings of a group." 281 Groups are connected not just by their united belief system but by the emotional charge of the event, brought on by coordinated physical activity and bodily contact. William McNeill even believes that this type of musical embodiment has an evolutionary advantage, as it creates social bonds between group members and facilitates the formation of collective identity, thereby increasing the group's survivability. ${ }^{282} \mathrm{McNeill}$ calls the euphoric feeling of unity and camaraderie that comes from moving together in time "muscular bonding." He uses broad, sweeping historical examples to support the idea of muscular bonding, and his evidence lacks detail and specificity. However, McNeill's conclusions are supported by a study at Stanford University that found groups that had performed a synchronous activity (including marching, singing, and moving in time) were more likely to cooperate on a subsequent task than those who performed the same activity but non-synchronously. While their results do not prove or disprove the idea of "muscular bonding," they lead to the conclusion that synchronous collective rituals "may have therefore endowed some cultural groups with an advantage in societal evolution." 283

\footnotetext{
281 James M. Jasper, "The Emotions of Protest: Affective and Reactive Emotions In and Around Social Movements," Sociological Forum 13, 3 (1998): 418.

${ }^{282}$ William Hardy McNeill, Keeping Together in Time: Dance and Drill in Human History (Cambridge, MA: Harvard University Press, 1997), 4.

${ }^{283}$ Scott S. Wiltermouth and Chip Heath, "Synchrony and Cooperation," Psychological Science 20, no.1 (2009): 5.
} 
Participants in les casseroles often describe the sense of community and interconnectedness they gained from playing, singing, chanting and dancing in unison, even with strangers. Describing the appeal of les manifs casseroles, Rosen writes, "It's a wonderful feeling to wander through the streets, slowly picking up more neighbours and strangers. Everyone is smiling at newcomers, people wave and cheer from balconies. The warm sense of expanding collectivity is joyous and playful." 284

Carolina Echeverria, a Chilean-Canadian artist who participated in the antiPinochet protests in Chile of the 1980s as well as in the 2011 Québec student movement, describes the feeling of connectedness she experienced protesting. Living with family and in a neighbourhood that supported the Pinochet regime when she opposed it, she felt fearful, isolated and alone. Being able to participate in cacerolazos brought an end to her feelings of alienation or isolation: for her and other participants, "other people's banging would make us feel that we were not alone-and we would feel much stronger." ${ }^{285}$ As Charles Keil writes, "participation is the opposite of alienation."286

More than simply envoicing protest, though, les casseroles could be said to embody it. In his book Percussion: Drumming, Beating, Striking, John Mowitt discusses the musicological significance of the drum as connected to the body, both by the terms used for the parts of the drum (head, skin, body) and in the

\footnotetext{
${ }^{284}$ Rosen, 2012.

${ }^{285}$ François-Olivier Chené, Phillip Oxhorn, and Caroline Echeverria. Interview by Erica Johnson, The Current, CBC, June 1, 2012. http://www.cbc.ca/thecurrent/episode/2012/06/01/casseroleprotests/.

${ }^{286}$ Charles Keil, "Participatory Discrepancies and the Power of Music," Cultural Anthropology, 2/3 (August 1987): 276.
} 
way that many cultures actually regard drums as living beings-for example, "talking drums" are used as a method of mass communication in some indigenous African cultures. ${ }^{287} \mathrm{He}$ also notes that the body has been percussive all throughout history, whether in the creation of music or through violence such as beating, slapping, whipping, or striking. All of these situations are highly physical and social; the body functions as "the site of social contact in its most banal and intractable sense." ${ }^{288}$ Because of this, percussion is a uniquely physical and social type of instrument. The amplification of the body-in this case the body of the drum, standing in place of the human body—mobilizes people through the percussive field, "the beating that assembles sounds and bodies and the practices that articulate them." 289 Les manifs casseroles turned commodities such as pots and pans into instruments, paired them with the physical, social, and percussive act of marching, and created a musical congregation of instruments and bodies.

Using Mowitt's line of thought, when percussion is associated with protest, it could take on even greater semiotic dimensions, representing the physical suffering of the protester. This is a particularly interesting perspective from which to approach les manifs casseroles and its historical predecessors. During the "March of the Empty Pots and Pans," Chileans were attempting to call attention to the beating their bodies were supposedly taking from the government due to

\footnotetext{
${ }^{287}$ Aaron Mushengyezi, "Rethinking Indigenous Media: Rituals, Talking Drums, and Orality as Forms of Public Communication in Uganda," Journal of African Cultural Studies, 16, 1 (June 2003): 110-111. The sounds of the drums are learned from a young age so that they can be learned and identified as naturally as other spoken and written languages.

${ }^{288}$ John Mowitt, Percussion: Drumming, Beating, Striking (Durham, NC: Duke University Press, 2002), 6.

${ }^{289}$ Mowitt, Percussion, 6.
} 
lack of food, and under Pinochet the bodies of protesters and activists were literally being beaten by police and military forces. As Mowitt writes, "there is something extraordinary about the importance of beating, of creating a specifically percussive din." ${ }^{290}$ It is a highly evocative form of protest, whose meaning is shaped with rich symbolism and cultural references that acted as mobilization frames.

Charles Keil believes that it is the discrepancies in music that invite participation-for example, the rhythmic inconsistencies between sections of a band are what "create 'swing' and invite us to participate." ${ }^{291}$ He notes that some musical traditions celebrate pitch and textural discrepancies, such as Goral music, ${ }^{292}$ polka, jazz and music created by Tibetan Buddhist practitioners. ${ }^{293}$ Though these discrepancies are sometimes labeled imperfections, Keil feels that they can be energizing and makes the bold claim that all successful music contains them. ${ }^{294}$ Les manifs casseroles often featured such discrepancies, partly due to the large amount of space-and thus acoustic lag — that the protesters occupied, and in part because of sheer number and variety of participants. Keil's theory about discrepancies could explain some of the attraction people felt for les casseroles.

\footnotetext{
${ }^{290}$ Mowitt, Percussion, 98.

${ }^{291}$ Keil "Participatory Discrepancies and the Power of Music," 277.

${ }^{292}$ Music of the Gorale, a group of people indigenous to parts of Poland, Slovakia, and Czech Republic. An example of this discrepant music can be heard here: "Goral music Sucha Hora Bratia Šuvadovci," YouTube Video, 1:53, posted by vady243, August 26, 2009, http://www.youtube.com/watch?v=r7LOhtZzR-Y.

${ }^{293}$ Music in Tibetan monasteries often featured instruments paired together.

${ }^{294}$ Keil, "Participatory Discrepancies and the Power of Music," 279. While he mentions genres of music (such as jazz), he does not offer specific performances or pieces of music as examples.
} 
Ultimately, the success of les manifs casseroles was the result of its frame resonance: its volume replicated the defiance and demand for attention of the protesters, and its participatory nature emphasized inclusivity. Like many other ritualistic performances, it has the possibility of serving "as a means of dramatizing injustice, discharging distressing emotions, generating emotional energy, building solidarity, and affirming identity." ${ }^{295}$ Through the elements explored in this chapter, the students and their allies were successful in using les casseroles to construct meanings and perceptions of events alternative to those presented by the mass media and Charest's government. ${ }^{296}$ The framing of Bill 78 as a necessity for restoring order was subsequently rejected, turning, as Marcela Fuentes puts it, "docile compliers of everyday norms into true contenders." ${ }^{297}$

${ }^{295}$ Aminzade and McAdam, "Emotions and Contentious Politics," 42.

${ }^{296}$ This applies particularly to English language media, as noted by Anna from http://translatingtheprintempserable.tumblr.com, and as exemplified in Margaret Wente's The Globe and Mail editorial (see chapter 1, page 26).

${ }^{297}$ Fuentes, 13. 
Berntson 105

\section{Conclusion}

We have seen throughout this study that the concept of casserole-based protest, in all its manifestations, has a remarkable capacity to mobilize citizens. Repurposed as an instrument of protest, the cooking casserole has become a potent symbol in Québec and, indeed, throughout the world, its sound coming to signify rebellion. Les manifs casseroles offer an example of its power to embody protest through percussive sound as an act of collective resistance. In Québec, the casserole protests played several interrelated roles: they expanded the protests beyond student participants, recruited new allies for the student movement and turned public sentiment against Bill 78 to the protesters' advantage. They increased national and international media interest in the movement, generating sympathetic demonstrations in solidarity within North America and overseas, and acted as a tool for communities to hold authority figures accountable to the general public.

Les manifs casseroles is a form of collective musical demonstration whose history spans centuries and continents: a medieval ritual aiming to castigate sexual immorality that was recast as a rebellious political act in $19^{\text {th }}$ century Lower Canada, and a popular Chilean protest method that has expanded first across South America and then outside of it. The similarities it bears to the charivari and the cacerolazo, which were used in similar activist awakenings in Chile and other South American countries and in Lower Canada, are particularly instructive; together they create a fascinating trio of case studies for the casserole as a mode of expression. In each case the instrument-casserole 
overturns or redistributes existing power structures, if only temporarily. It is adaptable and versatile, but most often used by those who, due to language, class, or gender, often experience barriers within the traditional hierarchies of music-making and politics. And in each example the police and/or governments attempted—ineffectively—to contain or suppress the protests, yet the sound of casseroles rises as strident, pervasive and difficult to restrict.

The political purpose of les casseroles is adaptable, but it seems to accompany periods of reflection on a community's shared values and the construction, reinforcement or adjustment of existing values. The collective practices are, in large part, about self-definition: the ability of a community to define itself and speak for itself. Crane describes the capacity of ritual or ceremonial enactments to "invite self-definition into visible and audible performance." ${ }^{298}$ It is my contention that les casseroles represent one way to accomplish this through performance, for as Crane writes, "Performance encompasses the accouterments, gestures, and words through which people express their relation to a particular social moment." ${ }^{299}$ This essentially frames the experience for both participants and for bystanders/casual participants, such as those who join in from balconies and front steps without marching in the actual protest.

Though highly successful, les casseroles were a short-lived part of the student movement in Québec. Used at a time when the movement needed to reframe itself, they signaled a period of crisis, demanding urgent action:

${ }^{298}$ Crane, The Performance of Self, 175.
${ }^{299}$ Crane, The Performance of Self, 176. 
The repetition of cacerolazos or the proliferation and permanence of pickets are the symptom of the malfunctioning of the system of representation... Even though street actions proved highly effective in voicing people's discontent, and they offered provisional solutions in a stage of generalized crisis, they are meant to be transitory stages towards a revitalized institutional power. ${ }^{300}$

The performances, constantly in transition as they are, also represent political and social transition from one condition to another. For these transitions to occur, a disruption to the status quo must occur, ${ }^{301}$ and les casseroles provided such a disruption: they invaded public space and soundscapes, and reconfigured the established narrative on the student protests.

Despite occupying this transitory position, les casseroles now appear to be an enduring addition to the lexicon of protest in Montréal. While the widespread success of the student protests of 2012 has not been replicated, casseroles have been used on several more recent notable occasions within Montreal. On the one-year anniversary of the Parti Québécois accession to power (September 4, 2013), a group of 200 protesters staged a casserole protest against $P Q$ cuts to health care and daycare. ${ }^{302}$ Throughout September, other demonstrations against the PQ's controversial Charter of Québec Values frequently featured casseroles, ${ }^{303}$ attracting as many as 40,000 by some

\footnotetext{
${ }^{300}$ Fuentes, 132.

${ }^{301}$ Fuentes, 201.

302 "Casserole Protesters Denounce the PQ Government," CTV Montreal, Sept. 5, 2013, http://montreal.ctvnews.ca/casserole-protesters-denounce-the-pq-government-1.1441206.

${ }^{303}$ The proposed charter would make it illegal for government employees to wear overt religious symbols, including headscarves, turbans, and hijabs. Its proponents say that it is a logical extension of the separation of church and state, while detractors feel that it is rooted in intolerance of non-Christian religions or even racism. Roger Annis, "Thousands march in Montreal against proposed 'Charter of Quebec Values,"' Rabble.ca, Sept. 18, 2013, http://rabble.ca/blogs/bloggers/roger-annis/2013/09/thousands-march-montreal-againstproposed-charter-quebec-values.
} 
estimates. ${ }^{304}$ The flexibility and ease of les manifs casseroles means that new social movements can readily adopt it, and while they are still a relatively recent occurrence for Montréalers, les manifs may prove to be a standard addition—or reimagining of an older tradition-that enriches the soundscapes of protest in Québec

Whether one agrees or disagrees with the protesters and their cause, the casserole protests proved to have great power as a creative practice of political engagement, and one for which participatory performance is central in order to communicate, excite and provoke thought and commentary. From an activist perspective, a politically engaged and expressive public is more likely to be an activist public. It is ultimately my hope that by interrogating the impassioned mobilization behind les casseroles, one of the largest acts of civil disobedience in Canadian history, we can better understand what motivates a complacent public to mass movement. If we accept that advocacy and engagement are worthy goals, then the protests provide a compelling example of how such engagement can be achieved—through sound. As Martin Daughtry writes, "we can be moved by sounds; we can be moved by the resilience of the humans that produced them; and we can hope that they move us, if only incrementally, toward a more just life." ${ }^{305}$

${ }^{304} 20000$ by move conservative estimates. Annis, "Thousands march in Montreal against proposed 'Charter of Quebec Values."'

${ }^{305}$ Daughtry, 260. 


\section{Bibliography}

\section{Academic Sources}

Abdelali Abdelkader. "Wave of change in the Arab World and Chances for a Transition to Democracy." Contemporary Arab Affairs 6, no. 2 (2013): 198210. Doi: http://dx.doi.org/10.1080/17550912.2013.782718

Alford, Violet. "Rough Music or Charivari." Folklore 70/4 (1959): 505-518.

Aminzade, Ronald R. and Doug McAdam. "Emotions and Contentious Politics." In Silence and Voice in Contentious Politics, edited by Ronald R. Aminzade et al. Cambridge, UK: Cambridge University Press, 2001.

Bailey, Derek. Improvisation: Its Nature and Practice in Music. Cambridge, MA: Da Capo Press, Inc.,1992.

Bakhtin, Mikhail. Rabelais and His World. Translated by Hélène Iswolsky. Bloomington, IN: Indiana University Press, 1984.

Baldez, Lisa. Why Women Protest: Women's Movements in Chile. Cambridge, UK: Cambridge University Press, 2002.

Barney, Darin. "The Truth of Le Printemps Erables." Theory and Event 15, no. 3 (2012). doi: http://10.1353/tae.2012.0054.

Benford, Robert D. "You Could be the Hundredth Monkey." The Sociology Quarterly 34, no. 2 (May 1993): 195-216.

Benford, Robert D. and David A. Snow. "Framing Processes and Social Movements: An Overview and Assessment." Annual Review of Sociology 26 (2000): 611-639.

Benoit Marcelle, Dictionnaire de la Musique en France aux XVII et XVIII. Paris: Fayard Publishing, 1992.

Campante, Filipe R. and David Chor. "Why Was the Arab World Poised for Revolution? Schooling, Economic Opportunities, and Arab Spring." The Journal of Economic Perspectives 26 (Spring 2012): 167-187. http://www.jstor.org/stable/41495309.

Cashmere, John. "The Social Uses of Violence in Ritual: Charivari or Religious Persecution?” European History Quarterly 21 (1991): 291-319.

Castañeda, Ernesto. "The Indignados of Spain: A Precedent to Occupy Wall Street." Social Movement Studies 11, no. 3 (November 2012): 309-319. 
Chapman, Owen. "The Revolution Will Be Sonic." Wi Journal of Mobile Media Special issue (2012). http://wi.mobilities.ca/the-revolution-will-be-sonic/.

Charles Keil, "Participatory Discrepancies and the Power of Music." Cultural Anthropology 2, no. 3 (August 1987): 275-283. http://www.jstor.org/stable/656427.

Coronato, Rocco. Jonson Versus Bakhtin: Carnival and the Grotesque. Amsterdam: Rodopi Bv Editions, 2003.

Costanza-Chock, Sasha. "Mic Check! Media Cultures and the Occupy Movement." Social Movement Studies 11 (2012): 375-385.

Crummett, Maria de Los Angeles. "El Poder Femenino: The Mobilization of Women Against Socialism in Chile." Latin American Perspectives 4/4 (Autumn, 1977): 103-113.

Daughtry, Martin J. "From Voice to Violence and Back." In Music, Politics, and Violence, edited by Susan Fast and Kip Pegley, 243-263. Middletown, CT: Wesleyan University Press, 2012.

De Lama, George. "Chile Marches Toward Freedom to the Beat of Pots and Pans." Chicago Tribune, September 11, 1988. Accessed October 28, 2012. http://articles.chicagotribune.com/1988-0911/news/8801290837_1_post-pinochet-chilean-military-regime.

Deaville, James. "The Envoicing of Protest: Occupying Television News Through Sound and Music." Journal of Sonic Studies 3/1 (October 2012). http://journal.sonicstudies.org/vol03/nr01/a05.

Della Porta, Donatella. "Eventful Protest, Global Conflicts: Social Mechanisms in the Reproduction of Protest," edited by Goodwin, Jeff and James M. Jasper, 256-276.. Contention in Context: Political Opportunities and the Emergence of Protest. Stanford, CA: Stanford University Press, 2012.

Dillon, Emma. The Sense of Sound: Musical Meaning in France, 1260-1330. New York: Oxford University Press, 2012.

Fuentes, Marcela. "In the Event of Performance: Media, Embodiment, and Politics in the Americas." PhD Diss., New York University, 2008.

Gauvard, Claude and Altan Gokalp. "Les Conduites de Bruit et leur Signification a la Fin du Moyen Age: Le Charivari." Annales, Histoire, Sciences Sociales 29/3 (1974): 693-704. 
Goffman, Erving. "Frame Analysis." In The Goffman Reader, edited by Charles Lemert and Ann Branaman, 149-166. Malden, MA: Blackwell Publishers Ltd.,1997.

Goodwin, Jeff and James Jasper. "Introduction." In Rethinking Social Movements: Structure, Meaning, and Emotion, edited by Jeff Goodwin and James Jasper, vii-x. Oxford, UK: Rowman \& Littlefield Publishers Inc., 2004.

Goodwin, Jeff and James Jasper. Contention in Context: Political Opportunities and the Emergence of Protest. Stanford, CA: Stanford University Press, 2012.

Greer, Allan. "From Folklore to Revolution: Charivaris and the Lower Canada Rebellion of 1837." Social History 15, no. 1 (1990): 25-43.

------. The Patriots and the People: The Rebellion of 1837 in Rural Lower Canada. Toronto: University of Toronto Press, 1993.

Guzman-Concha, Cesar. "The Students' Rebellion in Chile: Occupy Protest or Classic Social Movement." Social Movement Studies 11 (November 2012): 408-415.

Hughes, Neil. "Young People Took to the Streets and all of a Sudden all of the Political Parties Got Old': The 15M Movement in Spain" 10, no. 4 (November 2011): 407-413.

Järviluoma-Mäkelä,, Helmi. "Re-sounding Pleasure in Soundscape Studies." Wi Mobilities 7, no. 1 (March 2013). http://wi.mobilities.ca/re-soundingpleasure-in-soundscape-studies/\#sthash.XhvFNacF.dpuf.

Jasper, James M. "The Emotions of Protest: Affective and Reactive Emotions In and Around Social Movements." Sociological Forum 13, no. 3 (1998): 397424.

Jenkins, Craig J. and Michael Wallace. "Generalized Action Potential of Protest Movements: The New Class, Social Trends, and Political Exclusion Explanations." Sociological Forum 2, no. 2 (June 1996): 183-207. http://www.jstor.org/stable/684837.

Johnson, Loretta T. "Charivari/Shivaree: A European Folk Ritual on the American plains." Journal of Interdisciplinary History 20, no. 3 (1990): 371-387.

Johnston, Hank and John A. Noakes. "Frames of Protest: A Road Map to a Perspective." In Frames of Protest: Social Movements and the Framing Perspective, edited by Hank Johnston and John A Noakes, 1-32. Lanham, MD: Rowman \& Littlefield Publishers Inc., 2005. 
Keil, Charles. "Participatory Discrepancies and the Power of Music." Cultural Anthropology 2, no. 3 (August 1987): 275-283.

Lemay, Violaine and Marie-Neige Laperrière. "Student Protests and Government Somersaults: The Spring from a Law and Society Perspective." Canadian Journal of Law and Society 27 (2012): 339-450.

Levy, Jacob T. "The High Cost of Low Tuition in Quebec." Academic Matters, (November 2012): 12-16.

Lynes, Krista. "Clamouring out: Against the Privative Sphere." Wi: Journal of Mobile Media 6, no. 3 (June 2012). http://wi.mobilities.ca/clamouring-outagainst-the-privative-sphere/.

MacLeod, Roderick and Mary Anne Poutanen. "Little Fists for Social Justice: Anti-Semitism, Community, and Montréal's Aberdeen School Strike." Labour/Le Travail 70 (2012): 61-99.

Maynard, Riley Henderson. "Protest Music Lyrics, 1962-1975." PhD Diss., St. Louis University, 1995.

McAdam, Doug. "Revisiting the U. S. Civil Rights Movement: Toward a More Synthetic Understanding of the Origins of Contention." In Rethinking Social Movements: Structure, Meaning, and Emotion, give editors 201232. Oxford, UK: Rowman \& Littlefield Publishers Inc., 2004.

McCarthy, Michael A. "Occupying Higher Education: The Revival of the Student Movement." New Labor Forum 21/2 (Spring 2012): 50-55.

McNeill, William Hardy. Keeping Together in Time: Dance and Drill in Human History. Cambridge, MA: Harvard University Press, 1997.

Meyer, David S. "Tending the Vineyard: Cultivating Political Process Research." In Rethinking Social Movements: Structure, Meaning, Emotion, edited by Jeff Goodwin and James M. Jasper, 47-60. Oxford, UK: Rowman \& Littlefield Publishers, Inc., 2004.

Miller, Francesca. Latin American Women and the Search for Social Justice. Hanover, NH: University Press of New England, 1991.

Mowitt, John. Percussion: Drumming, Beating, Striking. Durham, NC: Duke University Press, 2002.

Mushengyezi, Aaron. "Rethinking Indigenous Media: Rituals, Talking Drums, and Orality as Forms of Public Communication in Uganda." Journal of African Cultural Studies 16, no. 1 (June 2003): 107-117. 
Natale, Simone. "Talking of Revolution, Again: Interview with Fred Turner." Wi Journal of Mobile Media 6/3 (2012). http://wi.mobilities.ca/talking-ofrevolution-again-interview-with-fred-turner/.

Nti, Nana Bemma. "Lessons from the Death of a Tunisian Salesman: A Commentary." African Security Review 22, no. 2 (June 2013): 78-84.

Palmer, Bryan D. "Discordant Music: Charivaris and Whitecapping in NineteenthCentury North America." Labour / Le Travail 3 (1978): 5-62.

Party, Daniel. "Beyond 'Protest Song': Popular Music in Pinochet's Chile (19731990)." In Music and Dictatorship in Europe and Latin America, edited by Roberto Illiano and Massimiliano Sala, 671-684. Turnhout: Brepols Publishers, 2012.

Pineault, Eric. "Québec's Red Spring: An Essay on Ideology and Social Conflict at the End of Neoliberalism." Studies in Political Economy 90 (Autumn 2012): 29-56.

Power, Margaret. Right-Wing Women in Chile: Feminine Power and the Struggle Against Allende, 1964-1973. University Park, PA: Pennsylvania State University Press, 2003.

Rentschler, Carrie. "On s'en Câlisse, la Loi Special: The Music Festival That Wasn't." Wi: Journal of Mobile Media Special Issue (2012). http://wi.mobilities.ca/on-sen-calisse-la-loi-special-the-music-festival-thatwasnt/.

Rosen, Joseph. "Multigenerational Casserole Orchestras: The New Face of Anarchist Insurgency." Wi: Journal of Mobile Media Special Issue (2012). http://wi.mobilities.ca/multigenerational-casserole-orchestras-the-newface-of-anarchist-insurgency/.

Roth, Stéphane and Isabelle Soraru. Dire la musique: À la limite. Paris: L'Harmattan, 2012.

Sarochan, Cayley. "The Québec Student Strike - A Chronology." Theory and Event 15, no. 3 (2012). doi:10.1353/tae.2012.0030.

Sawchuk, Kim. "La Grève est étudiant/e, la Lutte est Populaire: the Québec Student Strike." Canadian Journal of Communication 37/3 (2012): 499504. 
Small, Christopher. "Foreword." In Search and Reflect: A Music Workshop Handbook, edited by John Stevens. London, UK: Rock School Ltd., 1985.

-----. Musicking: The Meanings of Performing and Listening. Middletown, CT: Wesleyan University Press, 1998.

Sotirakopolous, Nikos and George Sotiropoulos. "'Direct Democracy Now!': The Greek Indignados and the Present Cycle of Struggles." Current Sociology 61, no. 4 (2013): 443-456.

Sterne, Jonathan. "Québec's Casseroles: On Participation, Percussion, and Protest." Theory and Event 15/3 (2012). http://muse.jhu.edu/journals/theory_and_event/v015/15.3S.sterne.html.

Tancons, Claire. "Occupy Wall Street: Carnival Against Capital? Carnivalesque as Protest Sensibility." e-flux 30 (December 2011). http://www.eflux.com/journal/occupy-wall-street-carnival-against-capital-carnivalesqueas-protest-sensibility/.

Tannen, Deborah. Framing in Discourse. Oxford, UK: Oxford University Press, 1993.

Tarrow, Sydney. Power in Movement. Cambridge, UK: Cambridge University Press, 1998.

Thomas, Gwynn. Contesting Legitimacy in Chile: Familial Ideals, Citizenship, and Political Struggle, 1970-1990. University Park, PA: Pennsylvania University Press, 2011.

Thompson, E. P. Customs in Common: Studies in Traditional Popular Culture. New York: New Press, 1992.

Tilly, Charles and Lesley J. Wood. Social Movements 1768-2012. Boulder, CO: Paradigm Publishers, 2012.

Tinsman, Heidi. Partners in Conflict: The Politics of Gender, Sexuality, and Labor in the Chilean Agrarian Reform, 1950-1973. Durham, NC: Duke University Press, 2002.

Vance, Eugene. "Le Jeu de la feuillée and the Poetics of Charivari." MLN 100, no. 4 (September 1985): 815-828. http://www.jstor.org/stable/2905483.

Villalobos-Ruminott, Sergio. "The Chilean Winter." Radical Philosophy 171 (2012): 11-15. http://www.radicalphilosophy.com/commentary/the-chileanwinter. 
Walgrave, Stefaan and Jan Manssens. "Mobilizing the White March: Media Frames as Alternatives to Social Movement Organizations." In Frames of Protest: Social Movements and the Framing Perspective, edited by Hank Johnston and John A Noakes, 113-142. Lanham, MD: Rowman \& Littlefield Publishers Inc., 2005.

Waylen, Georgina. "Rethinking Women's Political Participation and Protest: Chile 1970-1990." Political Studies 40/2 (1992): 299-314.

Wiltermouth, Scott S. and Chip Heath."Synchrony and Cooperation."

Psychological Science 20, no. 1 (2009): 1-5. doi: 10.1111/j.14679280.2008.02253.x.

\section{News Articles}

Bélair-Cirino, Marco. "Grand tintamarre contre la loi 78 - Les casseroles s'en mêlent." Le Devoir, May 24, 2012.

http://www.ledevoir.com/societe/actualites-en-societe/350783/lescasseroles-s-en-melent.

Cala, Andrés. "Spain's Indignados: The 'original' Occupy reemerges with force." Christian Science Monitor, May 16, 2012, http://www.csmonitor.com/World/Europe/2012/0516/Spain-s-IndignadosThe-original-Occupy-reemerges-with-force.

Chouinard, Tommy and Paul Journet. "Québec élargit son programme de prêts pour études supérieures." La Presse, April 5, 2012. http://www.lapresse.ca/actualites/education/201204/05/01-4512709-elargit-son-programme-de-prets-pour-etudes-superieures.php.

Cross, Allison. 'Canada's 'Maple Spring?' Dissecting the longest student protest in Québec's history." National Post, May 3, 2012. http://news.nationalpost.com/2012/05/03/quebec-student-strike/.

Forster, Stephanie. "Facts don't back the protesters' claims." The Chronicle Herald, May 6, 2012. http://thechronicleherald.ca/thenovascotian/93290facts-don-t-back-protesters-claims.

Franklin, Jonathan. "Four Chilean Student Leaders Make the Jump to Parliament." Truthout, November 18, 2013. http://truthout.org/news/item/20114-4-chilean-student-leaders-make-the-jump-toparliament.

------. "Chile's Commander Camila, the student who can shut down a city." The Guardian, August 24, 2011, 
http://www.theguardian.com/world/2011/aug/24/chile-student-leadercamila-vallejo.

Gallagher, Ryan. "The 'Occupy' Movement's Spanish Roots." New Statesman, October 11, 2011. http://www.newstatesman.com/blogs/thestaggers/2011/10/occupy-movement-madrid.

Goldman, Francesca. "Camila Vallejo, the world's most glamourous revolutionary." New York Times, April 5, 2012. http://www.nytimes.com/2012/04/08/magazine/camila-vallejo-the-worldsmost-glamorous-revolutionary.html?pagewanted=all\&_r=0.

Grève étudiante: un panda pour la gratuité scolaire." Huffington Post Quebec, May 15, 2012. http://quebec.huffingtonpost.ca/2012/05/15/panda-gratuitescolaire_n_1519899.html.

Hamilton, Graeme. "Student Association Ordered to Reimburse man $\$ 1,220$ in lost tuition after forced strike last year." National Post, August 19, 2013. http://news.nationalpost.com/2013/08/19/student-association-ordered-toreimburse--man-1220-in-lost-tuition-after-forced-strike-last-year/.

Hynes, Jim. "Mind the gap: Montmarquette says underfunding a real problem." McGill Newsroom, February 23, 2013.

http://www.mcgill.ca/newsroom/channels/news/mind-gap-montmarquettesays-underfunding-real-problem-225146.

Lalonde, Michelle. "Commission examining maple spring protests is on-track." The Gazette, August 30, 2013. http://www.montrealgazette.com/news/Commission+examining+maple+sp ring+protests+track/8852815/story.html.

Más de seis millones de españoles han participado en el Movimiento 15M." Corporación de Radio y Televisión Española, June 8, 2011, http://www.rtve.es/noticias/20110806/mas-seis-millones-espanoles-hanparticipado-movimiento- $15 \mathrm{~m} / 452598 . \mathrm{shtml}$.

Ottawa defends Bill 78 against UN critique." CBC.ca, June 19, 2012. http://www.cbc.ca/news/canada/Montréal/ottawa-defends-quebec-bill-78against-un-critique-1.1283594.

Perraux, Les. "How casseroles overcame cudgels on the streets of Montréal." The Globe and Mail, May 30, 2012. http://www.theglobeandmail.com/news/national/how-casserolesovercame-cudgels-on-the-streets-of-Montréal/article4219644/. 
Protests fizzling out? Crowds shrink notably despite call for mass rally." National Post, June 22, 2012. http://news.nationalpost.com/2012/06/22/crowdsnotably-shrinking-in--protests-is-the-movement-fizzling-out/.

Rocha, Roberto and Max Harrold. "Police round up 518 protestors in one night." Montréal Gazette, May 24, 2012.

http://www.montrealgazette.com/news/story.html?id=6668555.

Shields, Billy. "Were the Quebec student protests worth it?" Global News, September 21, 2013. http://globalnews.ca/news/858944/were-the-quebecstudent-protests-worth-it/.

Urback, Robyn. "Quebec's Student Strikers Turn on Themselves." National Post, May 2, 2012. http://fullcomment.nationalpost.com/2012/05/02/robynurback-quebecs-student-strikers-turn-on-themselves/.

Wente, Margaret. "Quebec's tuition protestors are the Greeks of Canada." The Globe and Mail, May 19, 2012.

http://www.theglobeandmail.com/commentary/quebecs-tuition-protestersare-the-greeks-of-canada/article4186821/.

\section{Websites}

Anna. Translating Le Printemps Érables. http://translatingtheprintempserable.tumblr.com.

Chené, François-Olivier, Phillip Oxhorn, and Caroline Echeverria. Interview by Erica Johnson, The Current, CBC, June 1, 2012.

http://www.cbc.ca/thecurrent/episode/2012/06/01/casserole-protests/.

Conlogue, Ray. "Why Did They Strike?" Literary Review of Canada, December, 2012. http://reviewcanada.ca/magazine/2012/11/why-did-they-strike/.

Cox, Ethan. "'There is no Right to Protest': Montreal Police Deny Charter Rights." Rabble.ca, March 23, 2013, http://rabble.ca/blogs/bloggers/ethancox/2013/03/there-no-right-protest-montreal-police-deny-charter-rights.

Fiddler, Richard. "Massive Demonstrations Support Students Striking Against Fee Hikes." Global Research, March 21, 2012. http://www.globalresearch.ca/massive-demonstrations-support--studentsstriking-against-fee-hikes/29882\#sthash.zWpxF2FP.dpuf.

"Goral music Sucha Hora - Bratia Šuvadovci." YouTube Video, 1:53, posted by vady243, August 26, 2009. http://www.youtube.com/watch?v=r7LOhtZzRY. 
Julinthesky. "Concert de Casseroles Contre la Loi Spéciale." Bang Bang Blog. May 23, 2012. http://julinthesky.bangbangblog.com/2012/05/23/concertde-casseroles-contre-la-loi-speciale/.

Klein, Alice. "Quebec Student Protests by the Numbers." Rabble.ca, June 5, 2012. http://rabble.ca/columnists/2012/06/quebec-student-protestsnumbers.

Labelle, Ronald. "Tintamarre: A New Acadian Tradition." Encyclopedia of French Cultural Heritage in North America, 2007, http://www.ameriquefrancaise.org/en/article319/Tintamarre:_a_New_Acadian_"Tradition”_.html.

Lazare, Sarah. "Colombia Nationwide Strike Against 'Free Trade', Privatization, Poverty." Common Dreams, August 25, 2013. https://www.commondreams.org/headline/2013/08/25.

"Le concert de casseroles atteint Montréal." Canoe.ca, May 23, 2012. http://fr.canoe.ca/infos/regional/archives/2012/05/20120523-191848.html.

"Libérez-nous Des Libéraux, Loco Locass," ParolesMania, http://www.parolesmania.com/paroles_loco_locass_58033/paroles_liberez -nous_des_liberaux_1123038.html.

Ling, Justin. " 3 rd night of protest under Bill 78: Calm in the streets, 2 arrests, conga line." Open File, May 22, 2012.

http://www.openfile.ca/Montréal/Montréal/text/3rd-night-protest-under-bill78-2-arrests-calm-streets-conga-line.

Loewen, Andrew. "From Cacerolazo to Casseroles, From the Kitchen to the Streets."Palty Sapien, May 27, 2012. http://www.thepaltrysapien.com/2012/05/from-cacerolazo-to-casserolesfrom-the-kitchen-to-the-streets/\#sthash.HLo3JtL8.dpuf.

"Manifesto." CLASSE, 2012. http://www.stopthehike.ca/manifesto/.

"Maple Spring: Nearly 1,000 Arrested as Mass Quebec Student Strike Passes 100th Day." Democracy Now! Friday May 25, 2012. http://www.democracynow.org/2012/5/25/maple_spring_nearly_1_000_arr ested.

"March 22 $2^{\text {nd }}: 200,000$ took to the streets!" CLASSE. http://www.stopthehike.ca/wp-content/uploads/2012/03/ExpressEN.pdf.

Milstein, Cindy. "Manifest Your Dreams, Montreal, Prelude to Night 73 (in C minor)." Outside the Circle, July 3, 2012. 
http://cbmilstein.wordpress.com/2012/07/03/manifest-your-dreamsmontreal-prelude-to-night-73-in-c-minor/.

Montrêal by Theme." Tourisme Montrêal. http://www.tourismemontreal.org/Discover-montreal/Montreal-by-theme.

Online Etymology Dictionary. http://www.etymonline.com/.

Pilgrim, David. "What Was Jim Crow?" Ferris State University, Year? http://www.ferris.edu/jimcrow/what.htm.

"Q\&A Crisis in Oaxaca." BBC, October 31, 2006. http://news.bbc.co.uk/2/hi/6102018.stm.

Renauld, Martin. "A short history of cacerolazos." Daily Gumboot, June 20, 2012. http://dailygumboot.ca/2012/06/a-short-history-of-cacerolazos/.

"Rêve Général Illimité au Festival du Jazz de Montréal " Howl Arts Collective, July 2, 2012. http://howlarts.net/post/26376871104/reve-general-illimiteau-festival-du-jazz-de-montreal.

Robert, Véronique. "Avoir peur de la police, pas des manifs." Voir.ca, March 23, 2013. http://voir.ca/veronique-robert/2013/03/23/avoir-peur-de-la-policepas-des-manifs/.

Ross, Alex. "The Satyagraha Protest (updated)." The Rest is Noise (blog), December 2, 2011. http://www.therestisnoise.com/2011/12/thesatyagraha-protest.html.

Schonbek, Amelia. "The Long March: On the front lines with Quebec's student protestors." The Walrus, September 12, 2012. http://thewalrus.ca/the-longmarch/?ref=2012.09-firsthand-the-long-march.

Serebin, Jacob. "Quebec's pots and pans protesters: Forget Tuition. It's all about Bill 78 now." Maclean's, May 5, 2012. http://oncampus.macleans.ca/education/2012/05/29/quebecs-pots-andpans-protesters/.

Stoller, Matt. "\#OccupyWallStreet Is a Church of Dissent, Not a Protest." Naked Capitalism, September 29, 2011. http://www.nakedcapitalism.com/2011/10/matt-stoller-the-anti-politics-ofoccupywallstreet.html.

"The October Crisis."

http://www.cbc.ca/history/EPISCONTENTSE1EP16CH1PA4LE.html. 
Wilson, William Moss. "Just Don't Call Her Che." The New York Times, January 28, 2012. http://www.nytimes.com/2012/01/29/opinion/sunday/studentprotests-rile-chile.html?pagewanted=all. 